\title{
NUTRIENT LOADING TO LEWISVILLE LAKE, NORTH-CENTRAL TEXAS, 1984-87
}

By W. Scott Gain and Stanley Baldys III

U.S. GEOLOGICAL SURVEY

Water-Resources Investigations Report 95-4076

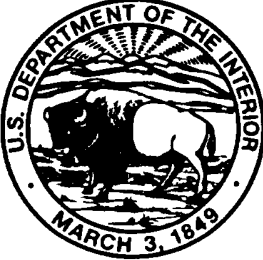

Prepared in cooperation with the CITY OF DALLAS 


\section{U.S. DEPARTMENT OF THE INTERIOR BRUCE BABBITT, Secretary \\ U.S. GEOLOGICAL SURVEY \\ Gordon P. Eaton, Director}

Any use of trade, product, or firm names is for descriptive purposes only and does not imply endorsement by the U.S. Government.

For additional information write to:

District Chief

U.S. Geological Survey 8011 Cameron Rd.

Austin, TX 78754-3898
Copies of this report can be purchased from:

U.S. Geological Survey

Earth Science Information Center

Open-File Reports Section

Box 25286, Mail Stop 517

Denver Federal Center

Denver, CO 80225-0046 


\section{CONTENTS}

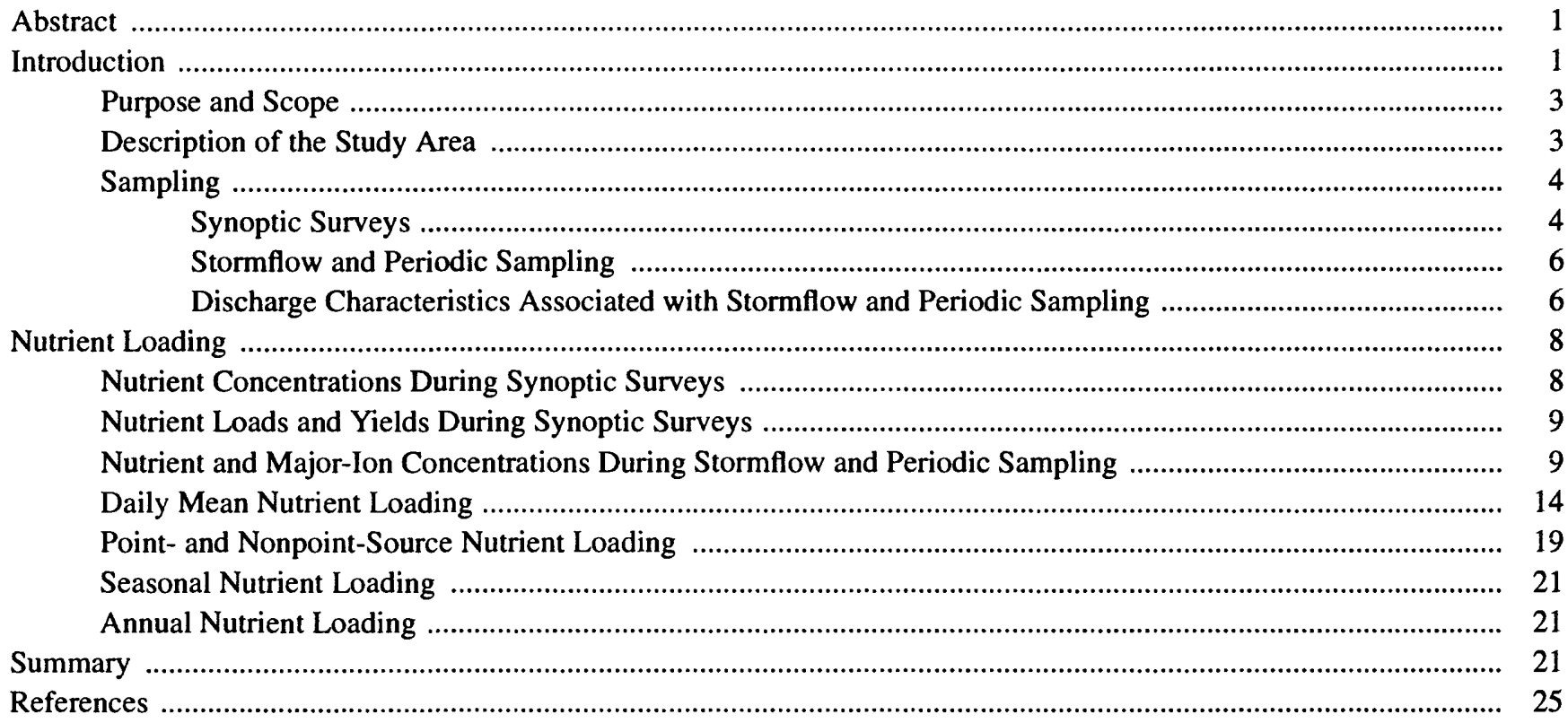

\section{PLATES}

[Plates are in pocket]

1. Map showing Lewisville Lake drainage basin and location of synoptic-survey sites, streamflowgaging stations used for stormflow and periodic sampling, sewage-treatment plants, and physiographic regions, north-central Texas

2. Map showing areal distribution of total nitrogen and total phosphorus concentrations in water sampled during two synoptic surveys in the Lewisville Lake drainage basin, north-central Texas

\section{FIGURES}

1. Map showing location of Lewisville Lake

2. Hydrographs showing daily mean discharge at streamflow-gaging stations used for stormflow and periodic sampling in the Lewisville Lake drainage basin, north-central Texas, 1986-87 water years

3. Boxplots showing range and distribution of nutrient concentrations in water at streamflow-gaging stations used for stormflow and periodic sampling in the Lewisville Lake drainage basin, north-central Texas, 1986-87 water years

4. Trilinear diagrams showing relation of major ions in water at streamflow-gaging stations used for periodic sampling in the Lewisville Lake drainage basin, north-central Texas, 1986-87 water years

5. Graphs showing nutrient-load transport curves for streamflow-gaging stations used for stormflow and periodic sampling in the Lewisville Lake drainage basin, north-central Texas, 1986-87 water years

6. Graphs showing cumulative percent of cumulative discharge and nutrient loads at various rates of daily mean discharge for streamflow-gaging stations in the Lewisville Lake drainage basin, north-central Texas, 1986 water year

7. Graphs showing monthly daily mean nutrient loads computed for streamflow-gaging stations and estimated for ungaged streams in the Lewisville Lake drainage basin, north-central Texas, 1986-87 water years 


\section{TABLES}

1. Location, physiographic region, and drainage area of synoptic-survey sites in the Lewisville Lake drainage basin

2. Discharge and daily mean nutrient loads and yields during low-flow (March 1984) and high-flow (March 1985) synoptic surveys in the Lewisville Lake drainage basin

3. Mean water-quality data for stormflow and periodic sampling at streamflow-gaging stations in the Lewisville Lake drainage basin, 1986-87 water years

4. Daily mean discharge and nutrient concentrations, loads, and yields for streamflow-gaging stations and ungaged streams in the Lewisville Lake drainage basin, 1986-87 water years

5. Estimates of average annual nutrient loads to Lewisville Lake

\section{CONVERSION FACTORS AND ABBREVIATIONS}

\begin{tabular}{|c|c|c|}
\hline Multiply & By & To obtain \\
\hline acre & 0.4047 & hectare \\
\hline acre-foot (acre-ft) & 1,233 & cubic meter \\
\hline cubic foot per second $\left(\mathrm{ft}^{3} / \mathrm{s}\right)$ & 0.02832 & cubic meter per second \\
\hline cubic foot per second per square mile $\left[\left(\mathrm{ft}^{3} / \mathrm{s}\right) / \mathrm{mi}^{2}\right]$ & 0.01093 & cubic meter per second per square kilometer \\
\hline foot $(\mathrm{ft})$ & 0.3048 & meter \\
\hline foot per second (ft/s) & 0.3048 & meter per second \\
\hline mile (mi) & 1.609 & kilometer \\
\hline million gallons per day (Mgal/d) & 0.04381 & cubic meter per second \\
\hline pound per day (lb/d) & 2.205 & kilogram per day \\
\hline pound per day per square mile $\left[(\mathrm{lb} / \mathrm{d}) / \mathrm{mi}^{2}\right]$ & 0.0639 & gram per square meter per year \\
\hline square mile $\left(\mathrm{mi}^{2}\right)$ & 2.590 & square kilometer \\
\hline
\end{tabular}

\section{Abbrevlations:}

cells/mL, cells per milliliter $\mathrm{mg} / \mathrm{L}$, milligram per liter 


\title{
Nutrient Loading to Lewisville Lake, North-Central Texas, 1984-87
}

\author{
By W. Scott Gain and Stanley Baldys III
}

\section{Abstract}

Concentrations of nutrients in the streams of the 1,660-square-mile Lewisville Lake drainage basin have some association with the two types of physiographic regions in the basin-prairie regions and cross timbers regions. Total nitrogen and phosphorus concentrations generally are larger in streams draining the prairie regions than in streams draining the cross timbers regions, a characteristic that might be accounted for in part by the fact that prairie regions tend to have more nutrient-rich, less-permeable soils than cross timbers regions. Most of the variability in nutrient loads is associated with variability in discharge. During a low-flow synoptic survey, the largest contributor of total nitrogen and total phosphorus (at the downstream-most site) was Isle du Bois Creek (815 pounds per day of total nitrogen and 146 pounds per day of total phosphorus). During a high-flow synoptic survey, the largest contributor of total nitrogen and total phosphorus (at the downstream-most site) was Elm Fork Trinity River $(4,620$ pounds per day of total nitrogen and 210 pounds per day of total phosphorus).

On the basis of results of stormflow and periodic sampling, the total nitrite plus nitrate nitrogen that entered the reservoir on the average each day during 1986 was 5,640 pounds per day, and during $1987,4,480$ pounds per day. During the same period, about one and one-half as much nitrogen in the form of total ammonia plus organic nitrogen entered the reservoir $(8,530$ pounds per day in 1986 and 7,020 pounds per day in 1987); and about one-fourth as much total phosphorus entered the reservoir during the period $(1,310$ pounds per day in 1986 and 1,080 pounds per day in 1987).
Point sources accounted for small fractions (probably less than 10 percent) of the total nutrient load from Clear Creek, Little Elm Creek, Hickory Creek, and Elm Fork Trinity River.

Most of the point-source load to Lewisville Lake could originate at a few sewage-treatment plants discharging to ungaged streams close to the reservoir.

The estimated long-term (1974-89 water years) average annual total nitrogen load (excluding loads from sewage-treatment plants in ungaged areas) is 11,800 pounds per day. The estimated long-term (1974-89 water years) average annual total phosphorus load (excluding loads from sewage-treatment plants in ungaged areas) is 1,100 pounds per day.

\section{INTRODUCTION}

Lewisville Lake in north-central Texas, on Elm Fork Trinity River north of the Dallas/Fort Worth metropolitan area (fig. 1), has a conservation capacity of 457,600 acre-ft. The reservoir (pl. 1) is formed behind Lewisville Dam (constructed by the U.S. Army Corps of Engineers in 1954) and is used for water supply, flood control, and recreation. The reservoir is the principal source of water for several cities and communities in the area, including Dallas.

For many years before and after impoundment of Lewisville Lake, Dallas water utilities have documented recurring taste and odor problems in water pumped from Elm Fork Trinity River below the reservoir. The taste and odor problems in water from Lewisville Lake generally are attributed to the growth of algal blooms in the summer that contribute to excessive external nutrient (nitrogen and phosphorus) loading (Lee and others, 1977). Taste and odor could be imparted to the water by the exudates of algae or by the products of anoxic degradation of the algal mass by bacteria. Algal cell counts in Lewisville Lake have 


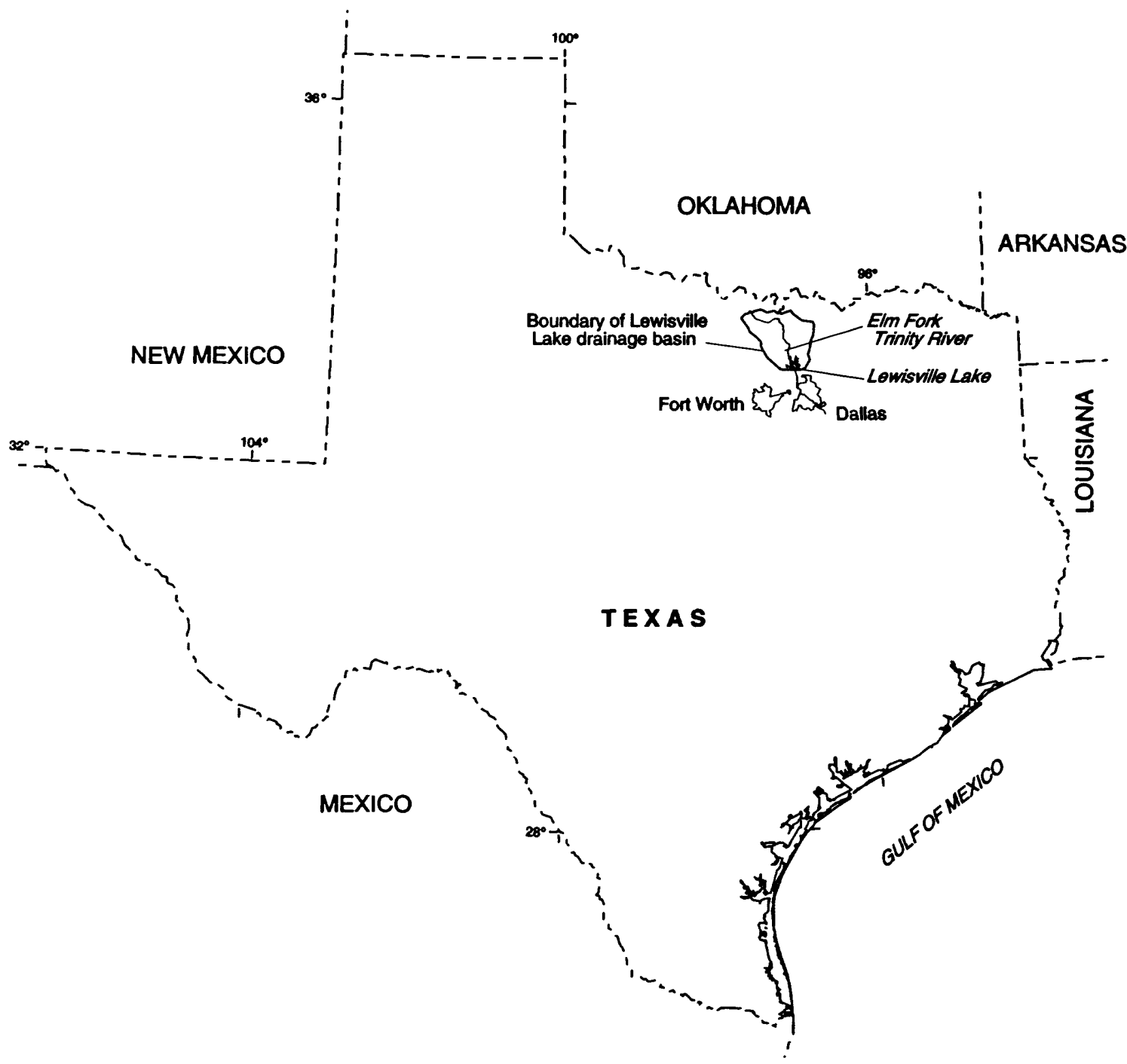

$\begin{array}{lllllll}0 & 50 & 100 & 150 & 200 & 100 & \text { MILES } \\ 0 & 50 & 100 & 150 & 200 & \text { KHLOMETERS }\end{array}$

Figure 1. Location of Lewisville Lake. 
been documented for most of the 1980-90 water years by the U.S. Geological Survey (1981-91) in reservoir water-quality surveys. (A water year is the 12-month period from October 1 through September 30 and is designated by the calendar year in which it ends.) In the summer, as many as 1.9 million cells $/ \mathrm{mL}$ have been present in samples of water from one arm of the reservoir. Cell counts in the winter usually have been considerably less (several thousand cells per millimeter).

Effective management of water quality and nutrient loading in Lewisville Lake requires knowledge of the quantity and source of loads from the drainage basin. (Loads and loading refer to the constituent materials transported by, suspended in, or deposited by water and measured by weight, which are discharged in a given time.) Nutrient loads originate as localized and identifiable point sources or as diffuse nonpoint sources. Many point sources can be identified and controlled. Nonpoint sources can be more difficult to identify and control because they are diffuse and often are associated with broad-based land-use practices.

Point- and nonpoint-source nutrient loads to Lewisville Lake historically have been estimated only indirectly. Pillard and Dickson (1988) sampled streamflow and computed nutrient loads for a part of the drainage basin; however, no documented studies have measured loads directly or attempted to estimate loads for the whole drainage basin of Lewisville Lake on the basis of observed discharge and nutrient-concentration data. Point-source nutrient loads have been estimated (DelRegno and Atkinson, 1988) using discharge data from sewage-treatment plants, but these loads were based on assumed or estimated nutrient concentrations. Reliable nutrient-concentration data for point-source effluents have been and continue to be difficult to collect. The U.S. Environmental Protection Agency (1977) and DelRegno and Atkinson (1988) estimated nonpoint-source nutrient loads using regional estimates of nutrient yields that were based on land use.

The U.S. Geological Survey, in cooperation with the City of Dallas, made a study of external nitrogen and phosphorus loading to Lewisville Lake during 1984-87. The study objectives were (1) to identify principal nutrient-load sources and to quantify nutrient loading in the drainage basin, and (2) to evaluate the relative magnitude of point- and nonpoint-source nutrient loading in the drainage basin.

\section{Purpose and Scope}

This report presents seasonal variations in loading and total annual loading of total nitrogen and phosphorus to Lewisville Lake from point and nonpoint sources.

\section{Description of the Study Area}

The Lewisville Lake drainage basin (study area for this report) encompasses a $1,660-\mathrm{mi}^{2}$ area of rolling woodland, open prairie, rangeland, and farmland in north-central Texas and includes parts of Collin, Cooke, Denton, Grayson, Montague, and Wise Counties (pl. 1). Land use includes limited suburban development and various kinds of animal husbandry and agriculture-horse and cattle ranches; dairy and sod farms; and cotton and numerous seed and grain crops.

Most of the drainage basin is sparsely populated. Denton and Gainesville are the two largest cities, accounting for most of the population in the area but only a small part of the total area (about $20 \mathrm{mi}^{2}$ or 1.2 percent). Suburban development covers a relatively small part of the drainage basin, concentrated in areas on the eastern and western sides of the reservoir. In $1974,2.8$ percent of the drainage basin was commercial or residential. By 1986, commercial or residential areas had increased to 3.1 percent. One of the major changes in the drainage basin occurred in 1987 when Ray Roberts Lake on Elm Fork Trinity River (pl. 1) began filling with water. Also, between 1974 and 1986, about 21 percent of the drainage basin was converted from pasture to farmland (DelRegno and Atkinson, 1988).

Denton, Gainesville, and many small rural communities throughout the Lewisville Lake drainage basin operate sewage-treatment plants that discharge either directly into the reservoir or into streams flowing to the reservoir (pl. 1). The largest sewage-treatment plants are operated by Denton and The Colony; each plant routinely discharges from 3 to $10 \mathrm{Mgal} / \mathrm{d}$. Each of the remaining 27 plants in the drainage basin are licensed to discharge less than $1 \mathrm{Mgal} / \mathrm{d}$. Most discharge considerably less than $1 \mathrm{Mgal} / \mathrm{d}$, and some operate only intermittently. Total effluent discharged directly to Lewisville Lake during 1986-87 was estimated to be $19.3 \mathrm{ft}^{3} / \mathrm{s}$. Effluent data from the sewagetreatment plants were compiled in 1991 from files of individual plants.

The Lewisville Lake drainage basin comprises four physiographic regions (pl. 1) that are associated 
distinctly with topography, soils, vegetation, and agricultural land use (Austin, 1965). These regions are delineated by boundaries of the various geologic outcrops and formations that they commonly are associated with (University of Texas, Bureau of Economic Geology, 1967). From west to east (and geologically oldest to youngest) they are: (1) West Cross Timbers, (2) Grand Prairie, (3) East Cross Timbers, and (4) Texas Blackland Prairie.

Outcrops of sandstone underlying the West and East Cross Timbers regions tend to form low, rolling hills marked by deeply eroded, narrow stream channels with steep banks. Soils in these regions typically are well-drained, light-colored ultisols of loamy or sandyloam texture, moderate to good permeability, and depths varying from a few inches on rock promontories to several feet in broad shallow valleys (Ford and Pauls, 1980). The natural vegetation in these regions is a scrubby woodland of post oak, blackjack oak, and mesquite. This woodland marks the western extent of the eastern forests of North America and is a transition to the more arid upland prairies of the west. In general, the soils in these regions are fertile, but their agricultural use is limited by the ruggedness of the terrain. Much of the land remains woodland or has been converted to fruit or nut orchards.

Limestone and calcareous shales underlying the Grand Prairie and Texas Blackland Prairie regions form nearly level grassland plains of dark, heavy soils and typically support few trees except along broad, shallow stream channels. The soils are mostly deep, well-mixed mollisols or vertisols of high base saturation and clay content. They are poorly drained and moderately to poorly permeable (Ford and Pauls, 1980). The soils of the Texas Blackland Prairie generally contain more clay, are less well drained, and are somewhat less permeable than those of the Grand Prairie region. Most of the land in these regions is used extensively for agriculture, and little or none of the natural prairie indigenous to the area remains.

Five principal stream drainage areas ranging from about 130 to about $380 \mathrm{mi}^{2}$ account for about 75 percent of the Lewisville Lake drainage basin (table 1). The largest is Elm Fork Trinity River drainage area, followed by Clear Creek, Isle du Bois Creek, Hickory Creek, and Little Elm Creek drainage areas. The remaining 25 percent of the drainage basin consists of the reservoir and the lands immediately adjacent to it, including numerous small streams with drainage areas of about $20 \mathrm{mi}^{2}$ or less. All five principal streams are controlled to some extent by small flood-retention ponds, stock tanks, and reservoirs. The surface area of Lewisville Lake is about 23,000 acres, and its capacity is 457,600 acre- $\mathrm{ft}$ when filled to conservation pool level (U.S. Geological Survey, 1988). Mean hydraulic depth computed for Lewisville Lake is about $20 \mathrm{ft}$, and mean annual outflow during the 1955-87 water years was about $664 \mathrm{ft}^{3} / \mathrm{s}$. Computed mean hydraulicresidence time for Lewisville Lake is 0.97 year.

Ray Roberts Lake, another large water-supply reservoir built by the Corps of Engineers during this study, controls flow in Elm Fork Trinity River above Lewisville Lake. The reservoir began filling with water during July 1987. Ray Roberts Dam is about $25 \mathrm{mi}$ upstream from Lewisville Dam. The drainage basin of Ray Roberts Lake is about $700 \mathrm{mi}^{2}$, and the reservoir capacity at conservation pool level is about 800,000 acre-ft (U.S. Geological Survey, 1989).

\section{Sampling}

Synoptic surveys of discharge and streamflow quality were made at 29 sites (pl. 1) in the Lewisville Lake drainage basin during 1984-85. Stormflow and periodic samples were collected during the 1986-87 water years at three streamflow-gaging stations on Clear Creek, Little Elm Creek, and Hickory Creek (pl. 1). Periodic samples also were collected during the 1986-87 water years at a station on Elm Fork Trinity River below the outflow at Ray Roberts Dam (pl. 1).

\section{Synoptic Surveys}

The 29 synoptic-survey sites are on the headwaters and main stems of each of the principal tributaries as well as on some of the smaller streams in the areas adjacent to the reservoir (pl. 1). The sites are identified by a two-character alphanumeric symbol (table 1). The first character indicates drainage area, the second, downstream order. The drainage areas of 17 downstream-most sites constituted about 80 percent of the Lewisville Lake drainage basin (table 1). All 29 sites were sampled once in March 1984 during low flow and again in March 1985 when flows generally were higher. Two sites on Elm Fork Trinity River and two sites on Isle du Bois Creek were inundated when Ray Roberts Lake was filled (1989).

Each of the synoptic surveys was completed in 1 day. Instantaneous discharge, specific conductance, $\mathrm{pH}$, temperature, and dissolved oxygen were determined in the field (Gain, 1989). Samples for nutrient 
Table 1. Location, physiographic region, and drainage area of synoptic-survey sites in the Lewisville Lake drainage basin

[mi ${ }^{2}$, square miles; GP, Grand Prairie; ECT, East Cross Timbers; TBP, Texas Blackland Prairie]

\begin{tabular}{|c|c|c|c|}
\hline $\begin{array}{c}\text { Site } \\
\text { number } \\
\text { (pl. 1) }\end{array}$ & $\begin{array}{l}\text { Location of site or streamflow- } \\
\text { gaging station name } \\
\text { (station number) }\end{array}$ & $\begin{array}{l}\text { Physiographic } \\
\text { region }\end{array}$ & $\begin{array}{c}\text { Drainage area } \\
\left(\mathrm{mi}^{2}\right)\end{array}$ \\
\hline \multicolumn{4}{|c|}{ Hickory Creek drainage area: } \\
\hline H1 & North Hickory Creek at US 380 & GP & 39.4 \\
\hline $\mathrm{H} 2$ & South Hickory Creek at US 380 & GP & 20.1 \\
\hline $\mathrm{H} 3$ & Dry Fork Hickory Creek at US 380 & GP & 4.13 \\
\hline${ }^{1} \mathrm{H} 4$ & Hickory Creek at Denton, Tex. (08052780) & GP & 129 \\
\hline${ }^{1} \mathrm{H} 5$ & Fincher Branch at unnumbered county road & ECT & 5.62 \\
\hline \multicolumn{4}{|c|}{ Clear Creek drainage area: } \\
\hline $\mathrm{C} 1$ & Clear Creek at FM 455 & GP & 257 \\
\hline $\mathrm{C} 2$ & Duck Creek at FM 455 & GP & 31.4 \\
\hline $\mathrm{C} 3$ & Clear Creek near Sanger, Tex. (08051500) & GP & 295 \\
\hline${ }^{1} \mathrm{C} 4$ & Clear Creek at FM 2164 & GP & 323 \\
\hline${ }^{1} \mathrm{C} 5$ & Milam Creek at FM 2164 & GP & 12.4 \\
\hline \multicolumn{4}{|c|}{ Elm Fork Trinity River drainage area: } \\
\hline E1 & Elm Fork Trinity River at FM 2071 & GP & 182 \\
\hline E2 & Elm Fork Trinity River at FM 922 & GP & 265 \\
\hline E3 & Spring Creek at unnumbered county road & GP & 71.1 \\
\hline${ }^{1} \mathrm{E} 4$ & Elm Fork Trinity River near Sanger, Tex. (08050500) & GP & 381 \\
\hline \multicolumn{4}{|c|}{ Isle du Bois Creek drainage area: } \\
\hline I1 & Jordan Creek at unnumbered county road & ECT & 65.3 \\
\hline $\mathrm{I} 2$ & Isle du Bois Creek at unnumbered county road & ECT & 205 \\
\hline${ }^{1} \mathrm{I} 3$ & Isle du Bois Creek near Pilot Point, Tex. (08051000) & ECT & 266 \\
\hline \multicolumn{4}{|c|}{ Little Elm Creek drainage area: } \\
\hline L1 & Little Elm Creek at FM 455 & TBP & 46.7 \\
\hline${ }^{1} \mathrm{~L} 2$ & Little Elm Creek near Aubrey, Tex. (08052700) & ECT & 75.5 \\
\hline${ }^{1} \mathrm{~L} 3$ & Mustang Creek at FM 428 & ECT & 22.2 \\
\hline${ }^{1} \mathrm{~L} 4$ & Pecan Creek near Aubrey, Tex. (08052730) & ECT & 32.2 \\
\hline${ }^{1} \mathrm{~L} 5$ & Running Branch at FM 2931 & ECT & 2.79 \\
\hline \multicolumn{4}{|c|}{ Other streams in Lewisville Lake drainage basin: } \\
\hline${ }^{1} \mathrm{O} 1$ & Cooper Creek at unnumbered county road & ECT & 6.66 \\
\hline${ }^{1} \mathrm{O} 2$ & Alyne Branch at FM 424 & ECT & 7.02 \\
\hline${ }^{1} \mathrm{O} 3$ & Pecan Creek at FM 288 & ECT & 12.3 \\
\hline${ }^{1} \mathrm{O} 4$ & Button Branch at unnumbered county road & TBP & 14.8 \\
\hline${ }^{1} \mathrm{O} 5$ & Panther Creek at FM 423 & TBP & 20.3 \\
\hline${ }^{1} \mathrm{O} 6$ & Cottonwood Branch at FM 423 & TBP & 9.45 \\
\hline${ }^{1} \mathrm{O} 7$ & Stewart Creek at unnumbered county road & TBP & 8.73 \\
\hline
\end{tabular}

${ }^{1}$ Downstream-most sites.

analyses were collected using depth-integrating suspended-sediment samplers and standard U.S. Geological Survey methods such as equal-width increment or equal-depth increment (Guy and Norman, 1970; Rantz and others, 1982). Immediately after collection, all nutrient samples were chilled and preserved with mercuric chloride. Analyses for determination of total nitrite plus nitrate nitrogen, total ammonia plus organic nitrogen, total nitrogen, total phosphorus, and total organic carbon concentrations were done by the U.S. 
Geological Survey National Water Quality Laboratory in Arvada, Colorado, using standard analytical techniques (Skougstad and others, 1979).

\section{Stormflow and Periodic Sampling}

Following the synoptic surveys, the principal streams were selected for additional and more detailed study of nutrient-loading rates to evaluate and refine estimates of loading to the reservoir during stormflow conditions. Two of the streams had existing streamflow-gaging stations operated by the U.S. Geological Survey-Clear Creek near Sanger, Tex. (08051500, pl. 1), and Little Elm Creek near Aubrey, Tex. (08052700, pl. 1). A third streamflowgaging station was installed in July 1985 on Hickory Creek at Denton, Tex. $(08052780$, pl. 1).

Stations on the two remaining principal streams in the study area (Elm Fork Trinity River near Sanger, Tex., and Isle du Bois Creek near Pilot Point, Tex.) could not be sampled because of backwater from construction of Ray Roberts Lake. Therefore, a streamflow-gaging station was installed on Elm Fork Trinity River near Pilot Point, Tex. (08051130, pl. 1), immediately below Ray Roberts Dam to provide additional nutrient-load data.

Samples were collected at Clear Creek near Sanger, Little Elm Creek near Aubrey, and Hickory Creek at Denton for about three stormflow events in each wet season (January to June) during the 1986-87 water years. Samples were collected periodically during the 1986-87 water years at the stormflow sampling stations and also at Elm Fork Trinity River near Pilot Point.
An automatic, vacuum-type water sampler, actuated by a float switch, was installed at each of the three stations above Lewisville Dam. During storms, the samplers operated at regular intervals ( 1 to 6 hours depending on the site and season) and marked the time of each sample collection on an event recorder. After storms, selected samples were withdrawn from the samplers, treated with mercuric chloride, and chilled. Instantaneous discharges were determined for each sampling period using the stage recorded at the time of sample collection and the stage-discharge rating for the station. Some storm samples were collected manually with a depth-integrating suspended-sediment sampler. In addition to stormflow samples, periodic samples (about six per year) were collected at the three stations during various flow conditions. Periodic samples also were collected at Elm Fork Trinity River near Pilot Point.

All samples were analyzed for total nitrite plus nitrate nitrogen, total ammonia plus organic nitrogen, and total phosphorus concentrations. Periodic samples also were analyzed for specific conductance, $\mathrm{pH}$, hardness, and dissolved calcium, magnesium, sodium, potassium, sulfate, chloride, fluoride, and silica.

\section{Discharge Characteristics Associated with Stormflow and Periodic Sampling}

Daily mean discharge for the period of record at three streamflow-gaging stations used for stormflow and periodic sampling and one station used only for periodic sampling is given in the following table:

\begin{tabular}{|c|c|c|c|}
\hline Streamflow-gaging station & $\begin{array}{c}\text { Station } \\
\text { number } \\
\text { (pl. 1) }\end{array}$ & $\begin{array}{c}\text { Daily mean } \\
\text { discharge } \\
\left(\mathrm{ft}^{3} / \mathrm{s}\right)\end{array}$ & Period of record ${ }^{1}$ \\
\hline \multicolumn{4}{|c|}{ Stormflow and periodic sampling } \\
\hline Clear Creek near Sanger, Tex. & 08051500 & 87.0 & $1950-87$ \\
\hline Little Elm Creek near Aubrey, Tex. & 08052700 & 46.4 & $1957-76,1980-87$ \\
\hline Hickory Creek at Denton, Tex. & 08052780 & 94.4 & $1986-87$ \\
\hline \multicolumn{4}{|c|}{ Periodic sampling } \\
\hline Elm Fork Trinity River near Pilot Point, Tex. & 08051130 & 2284 & $1950-84,1986-87$ \\
\hline
\end{tabular}




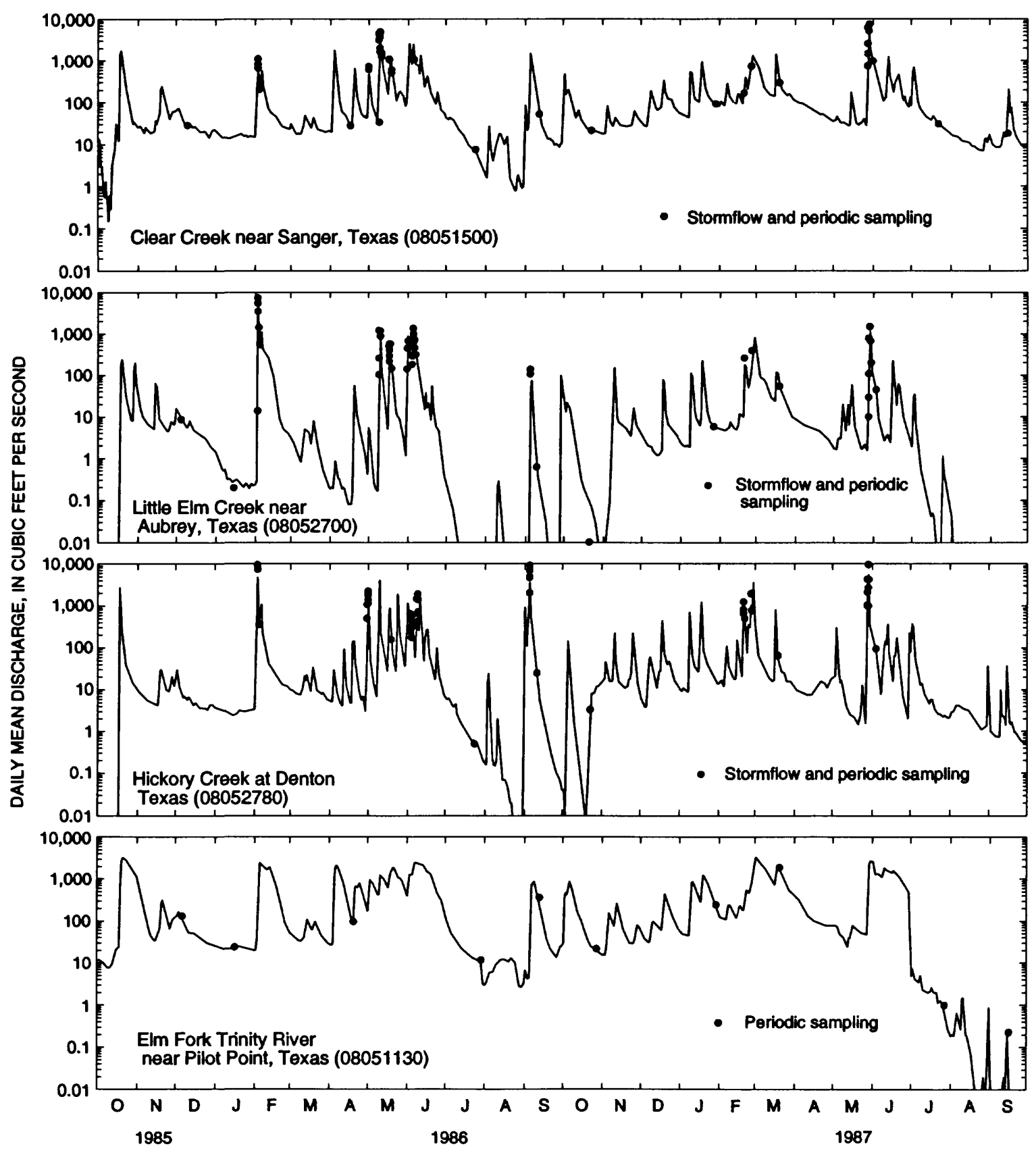

Figure 2. Hydrographs showing daily mean discharge at streamflow-gaging stations used for stormflow and periodic sampling in the Lewisville Lake drainage basin, north-central Texas, 1986-87 water years.

Daily mean discharges ranged from 0.01 to $10,000 \mathrm{ft}^{3} / \mathrm{s}$ during the $1986-87$ water years at the stations used for stormflow and periodic sampling (fig. 2). Although stormflow peaks can arrive and pass within several hours, rises can last more than several days. During stormflows, the stage-discharge relation is channel controlled and streamflow velocities can range from 1 to $4 \mathrm{ft} / \mathrm{s}$. Travel times from the stormflow sam- pling stations to the reservoir at these velocities might be as short as several hours. During low flows, water in these streams moves through a series of pools and riffles where flow velocities range from less than $0.1 \mathrm{ft} / \mathrm{s}$ (in pools) to more than $2 \mathrm{ft} / \mathrm{s}$ (in riffles).

The 1986-87 water years generally were wetter than normal. Daily mean discharge for the 1986-87 water years at Clear Creek near Sanger was $152 \mathrm{ft}^{3} / \mathrm{s}$ 
(U.S. Geological Survey, 1987-88) or about 6 percent larger than the 1981-87 water-year daily mean discharge of $143 \mathrm{ft}^{3} / \mathrm{s}$ (U.S. Geological Survey, 1988). The 1981-87 daily mean discharge was computed from records reflecting the effects of 51 floodwater-retarding structures in the Lewisville Lake drainage area that had been completed by 1980 . The daily mean discharge for the 1986-87 water years at Little Elm Creek near Aubrey was $37.2 \mathrm{ft}^{3} / \mathrm{s}$ (U.S. Geological Survey, 198788 ) or about 20 percent less than the 1957-76, 1980-87 water-year daily mean discharge of $46.4 \mathrm{ft}^{3} / \mathrm{s}$. There is no long-term record for Hickory Creek at Denton to compare with the daily mean discharge of $94.4 \mathrm{ft}^{3} / \mathrm{s}$ for the 1986-87 water years. Daily mean discharge for the 1986-87 water years at Elm Fork Trinity River near Pilot Point was $401 \mathrm{ft}^{3} / \mathrm{s}$ (U.S. Geological Survey, 1987-88) or about 45 percent larger than the sum of the 1950-84 water year average-annual discharges (277 $\left.\mathrm{ft}^{3} / \mathrm{s}\right)$ for Elm Fork Trinity River near Sanger and Isle du Bois Creek near Pilot Point (U.S. Geological Survey, 1985). Daily mean discharge at the Lewisville Lake outflow station (Elm Fork Trinity River near Lewisville) for the 1986-87 water years was $950 \mathrm{ft}^{3} / \mathrm{s}$ (U.S. Geological Survey, 1987-88) or about 43 percent larger than the average-annual discharge since the reservoir was impounded $\left(664 \mathrm{ft}^{3} / \mathrm{s}, 1955-87\right)$ (U.S. Geological Survey, 1988).

\section{NUTRIENT LOADING}

\section{Nutrient Concentrations During Synoptic Surveys}

The nutrient concentrations determined from the two synoptic surveys varied widely from site to site (pl. 2). The rank (or percentile) of each measured total nitrogen and total phosphorus concentration is indicated on plate 2 .

Total nitrogen concentrations ranged from 0.50 to $8.0 \mathrm{mg} / \mathrm{L}$ in the low-flow (March 1984) synoptic survey and from 0.60 to $16 \mathrm{mg} / \mathrm{L}$ in the high-flow (March 1985) synoptic survey (pl. 2). The largest concentration in the high-flow survey was at Stewart Creek (07). This stream also receives sewage effluent from The Colony sewage-treatment plant. Discharge for Stewart Creek during the high-flow survey was less than during the low-flow survey. Total nitrogen concentrations were generally smaller in the high-flow survey (median, $1.9 \mathrm{mg} / \mathrm{L}$ ) than in the low-flow survey (median, $2.3 \mathrm{mg} / \mathrm{L}$ ). A Wilcoxon signed-rank test
(Inman and Conover, 1983) on paired observations (high-flow/low-flow) indicated a 30-percent chance that this difference could have been random.

Data from the synoptic surveys indicate that total nitrogen concentrations could not be correlated with point-source inputs. Concentrations were largest in streams draining the Grand Prairie and Texas Blackland Prairie regions on the western and eastern sides of the reservoir (pl. 2). Because only some of the streams in these regions receive sewage effluent, nonpoint sources probably also contribute some nitrogen. The maximum total nitrogen concentration in the low-flow survey was in a stream (H2) in that part of the Hickory Creek drainage area not receiving sewage effluent. Total nitrogen concentrations were equal to or greater than the high-flow and low-flow survey medians on the eastern side of the reservoir in Panther Creek (O5) and Mustang Creek (L3), streams also not receiving sewage effluent. Large concentrations in Little Elm and Stewart Creeks probably represent a combination of point and nonpoint sources of nutrient loads.

The generally larger total nitrogen concentrations in streams of the prairie regions relative to concentrations in streams of the cross timbers regions indicate that total nitrogen concentrations might be more a function of soil type or agricultural land use than of sewage-effluent discharge. Because the Grand Prairie and Texas Blackland Prairie regions are farmed more intensively than the cross timbers regions and have more nutrient-rich, less-permeable soils, they might contribute more nitrogen from natural and/or agricultural processes to surface-water runoff.

Total phosphorus concentrations ranged from 0.02 to $0.63 \mathrm{mg} / \mathrm{L}$ during the low-flow survey and from 0.01 to $0.41 \mathrm{mg} / \mathrm{L}$ during the high-flow survey. Although the maximum concentration in the high-flow survey $(0.41 \mathrm{mg} / \mathrm{L})$ was smaller than in the low-flow survey $(0.63 \mathrm{mg} / \mathrm{L})$, the high-flow survey had a larger median total phosphorus concentration $(0.12 \mathrm{mg} / \mathrm{L})$. A Wilcoxon signed-rank test on paired observations did not indicate a statistically significant difference at the 95-percent confidence level between total phosphorus concentrations in the high- and low-flow surveys.

Physiographic region and sewage-effluent discharge appear to influence total phosphorus concentrations. Total phosphorus concentrations from streams draining the prairie regions were generally larger than those from streams draining the cross timbers regions. Within physiographic regions, the streams receiving sewage effluent had somewhat larger total phosphorus 
concentrations than streams with no sewage-effluent discharge.

\section{Nutrient Loads and Yields During Synoptic Surveys}

Nutrient loads (in pounds per day) were computed for each synoptic survey site (table 2) by multiplying measured (instantaneous) discharge (in cubic feet per second) by nutrient concentration (in milligrams per liter) by 5.39 (a units conversion factor). Loads at the downstream-most sites of individual drainage areas were summed to determine total loads from about 80 percent of the Lewisville Lake drainage basin.

Discharge tends to be more variable than concentration. Consequently, most of the variability in loads can be associated with discharge. During the low-flow survey, the largest contributors of total nitrogen (at the downstream-most sites) to Lewisville Lake were Isle du Bois Creek ( $815 \mathrm{lb} / \mathrm{d}$, or 24 percent of total load) and Hickory Creek $(621 \mathrm{lb} / \mathrm{d}$, or 18 percent). The largest contributors of total phosphorus were Isle du Bois Creek (146 lb/d, or 50 percent) and Elm Fork Trinity River $(59.5 \mathrm{lb} / \mathrm{d}$, or 21 percent). During the high-flow survey, the largest contributors of total nitrogen and total phosphorus were Elm Fork Trinity River $(4,620$ $\mathrm{lb} / \mathrm{d}$, or 41 percent, and $210 \mathrm{lb} / \mathrm{d}$, or 31 percent, respectively) and Clear Creek $(2,460 \mathrm{lb} / \mathrm{d}$, or 22 percent, and $175 \mathrm{lb} / \mathrm{d}$, or 26 percent, respectively).

Storm-generated discharge typically produces changes in nutrient concentrations in streamflow. Nutrient concentrations are expected to decrease as discharge increases. Streams receiving sewage effluent have relatively larger nutrient concentrations in low flows than in high flows. A change in load relative to a change in discharge between the two surveys indicates the degree to which streams are influenced by sewageeffluent discharge. At the downstream-most sites, discharge in the high-flow survey was about 3.7 times that in the low-flow survey (table 2). Total nitrogen load was about 3.3 times larger and total phosphorus load about 2.3 times larger in the high-flow survey than in the low-flow survey.

Yields, or loads per unit area (table 2), allow direct comparisons between basins. Average nutrient yields for $1,329 \mathrm{mi}^{2}$ ( 80 percent) of the Lewisville Lake drainage basin included in the synoptic surveys were 2.5 and $8.4(\mathrm{lb} / \mathrm{d}) / \mathrm{mi}^{2}$ of total nitrogen and 0.22 and $0.51(\mathrm{lb} / \mathrm{d}) / \mathrm{mi}^{2}$ of total phosphorus in the low-flow and high-flow surveys, respectively (table 2). Highflow yields were similar to those reported by Rast and Lee (1983) for rural/agricultural areas and those used by DelRegno and Atkinson (1988) - about $8(\mathrm{lb} / \mathrm{d}) / \mathrm{mi}^{2}$ for total nitrogen and $0.8(\mathrm{lb} / \mathrm{d}) / \mathrm{mi}^{2}$ for total phosphorus. Some of the largest yields in both surveys were from the three streams receiving the largest amounts of sewage effluent, relative to their discharges-Elm Fork Trinity River, Little Elm Creek, and Stewart Creek. Clear Creek, with one of the largest drainage areas, was one of the large contributors of total load but had small yields. Hickory Creek, also one of the large contributors of total nitrogen load in the low-flow survey, had smaller total nitrogen yields than Clear Creek in the high-flow survey. The Denton sewage-treatment plant, downstream from a sampling site and near the reservoir, was not included in the synoptic surveys or subsequent stormflow and periodic sampling.

\section{Nutrient and Major-Ion Concentrations During Stormflow and Periodic Sampling}

The range and distribution of nutrient data collected during the stormflow and periodic sampling are shown by boxplots (fig. 3). The nutrient data generally appear to be log-normally distributed and generally are skewed toward smaller concentrations, similar to nutrient data collected during the synoptic surveys.

A summary of water-quality data collected during the 1986-87 water years at the stations used for stormflow and periodic sampling is shown in table 3. Nutrient concentrations were determined for the stormflow and periodic samples. Major-ion concentrations were determined for the periodic samples to help identify sources of point and nonpoint loading.

Large mean total nitrite plus nitrate nitrogen concentrations and mean total phosphorus concentrations in samples collected at Little Elm Creek near Aubrey during the stormflow and periodic sampling are consistent with the synoptic survey results and might be related to sewage-effluent loading of the streams. Mean total ammonia plus organic nitrogen concentrations were largest in Hickory Creek.

Calcium generally was the dominant cation (mean concentrations range from 51 to $69 \mathrm{mg} / \mathrm{L}$, table 3 ), and alkalinity expressed as calcium carbonate was the dominant anion (mean concentrations range from 120 to $169 \mathrm{mg} / \mathrm{L}$, table 3 ). These characteristics are consistent with the large $\mathrm{pH}$ and divalent cation content of the prairie soils. Trilinear diagrams (fig. 4) show the 

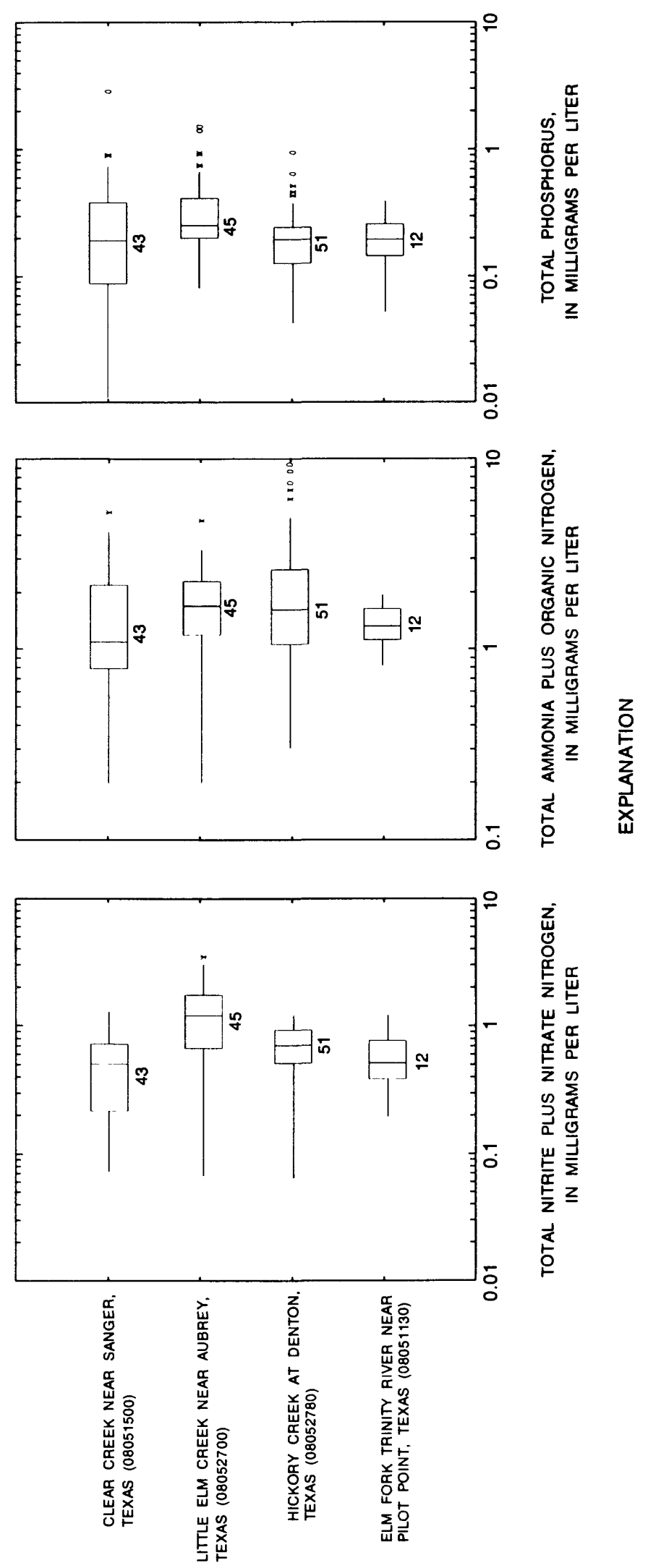

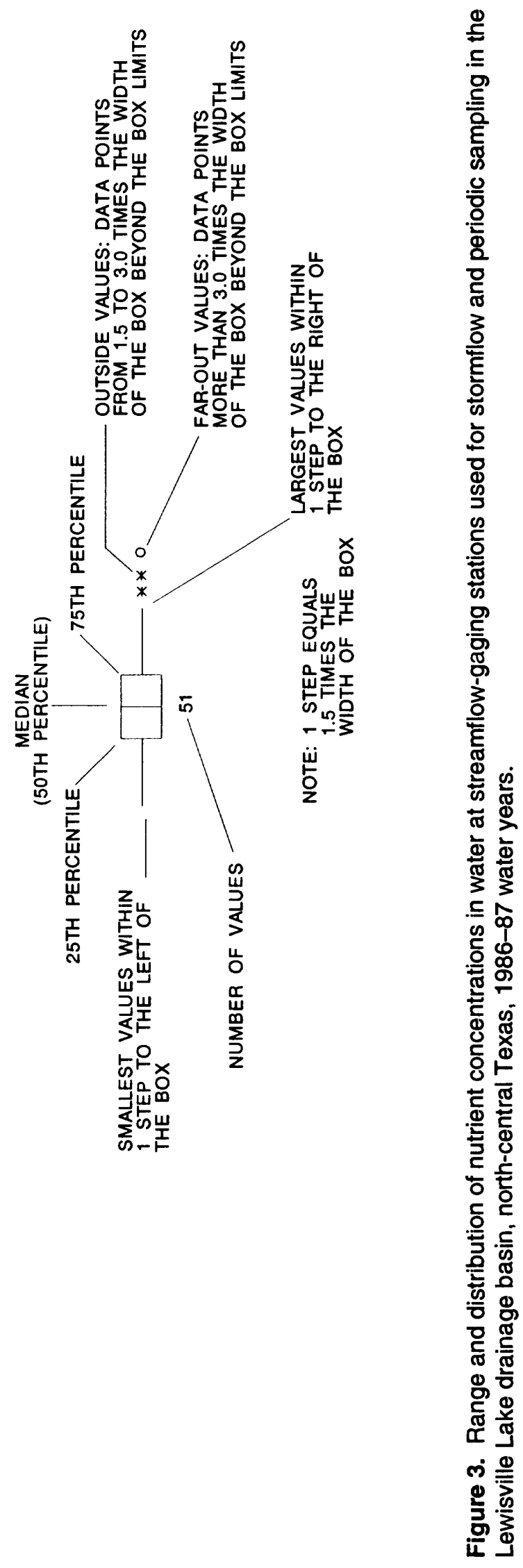



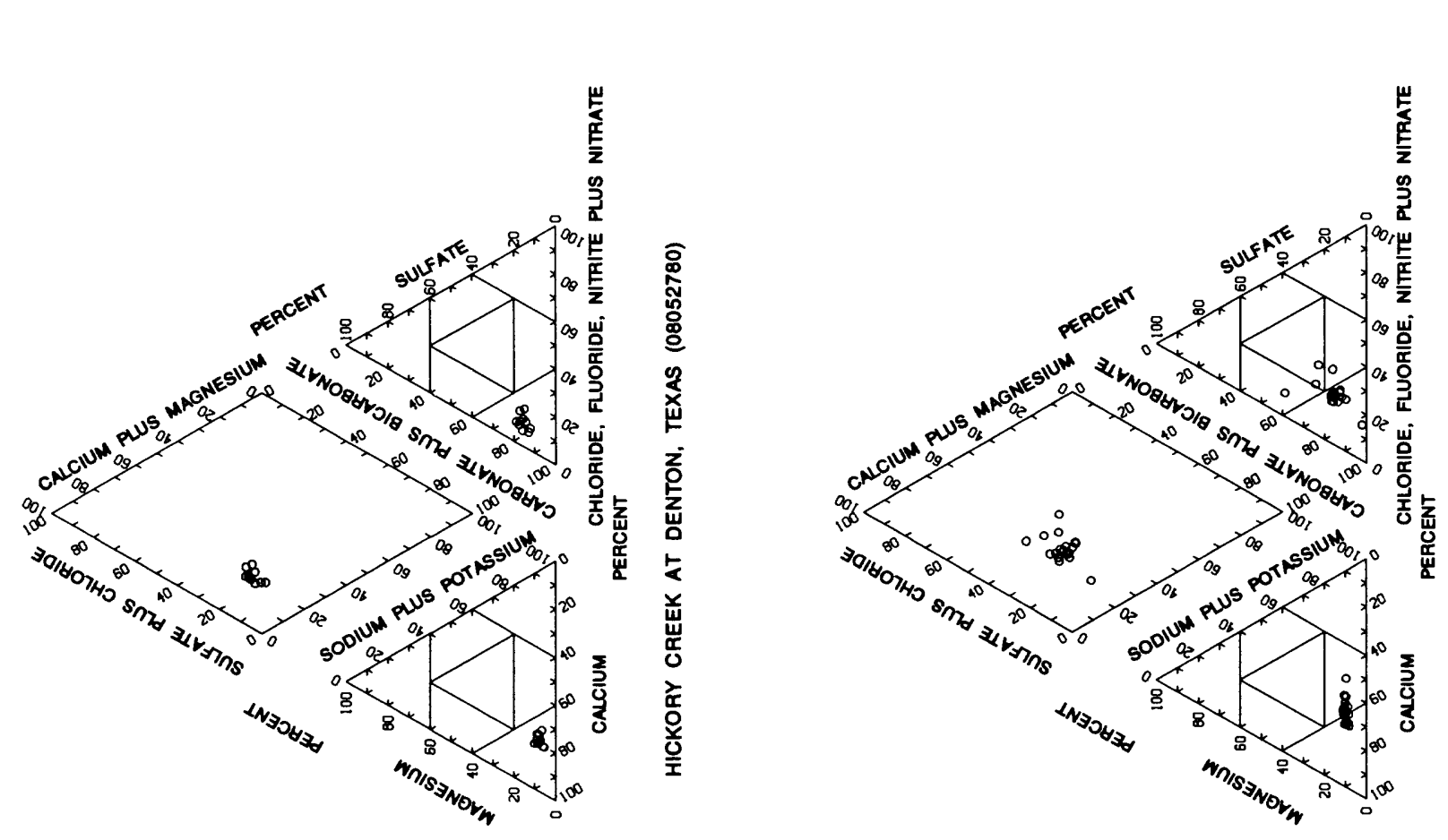

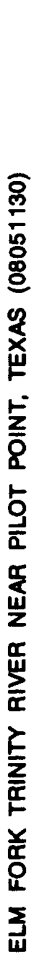
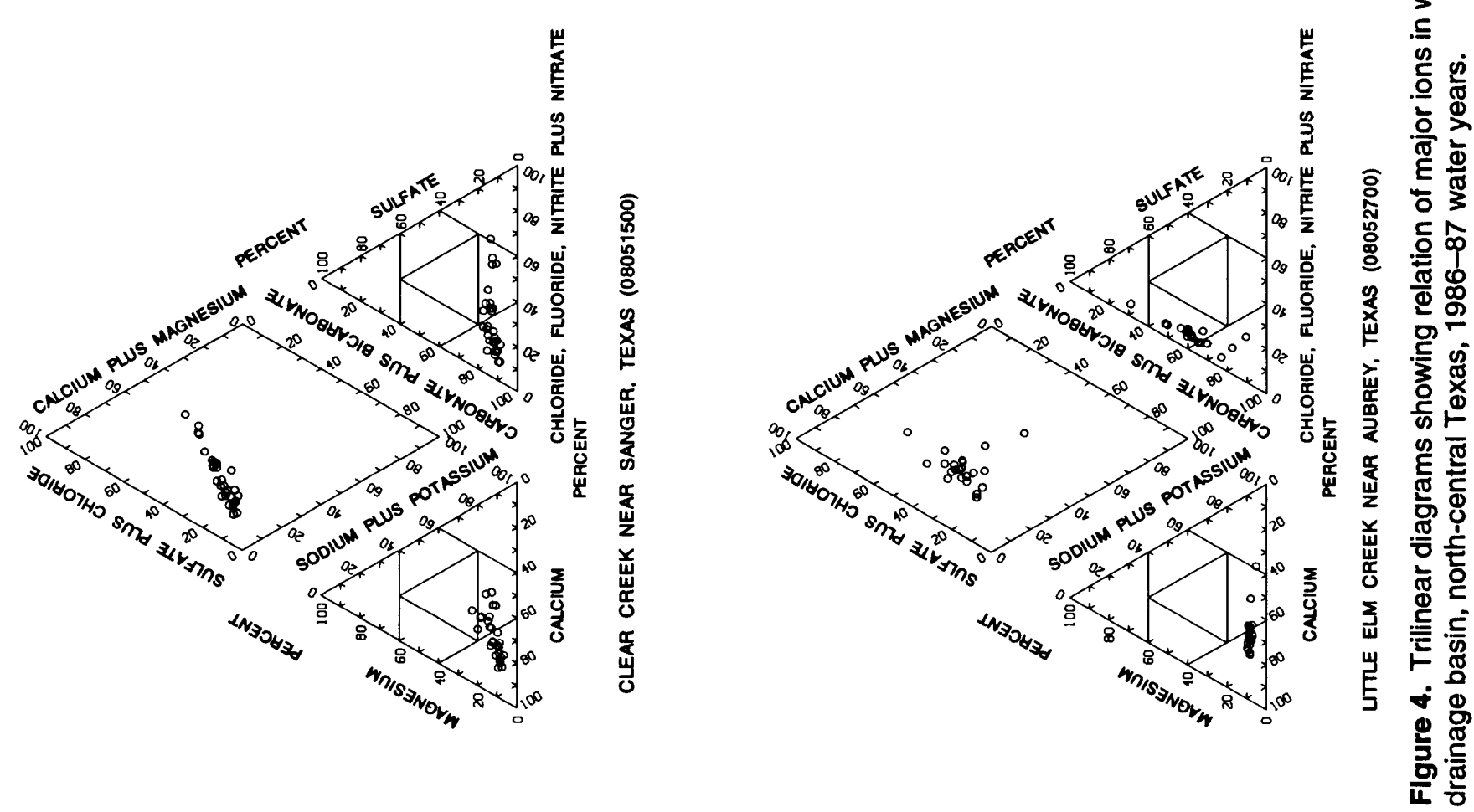
จ

吾

든

需

竞

인

$\sum$

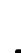

흠

몬

.

.

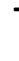

응

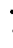

.

赵

ฐ

층

을

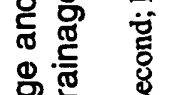

突造总

号学

ง

을

(4)

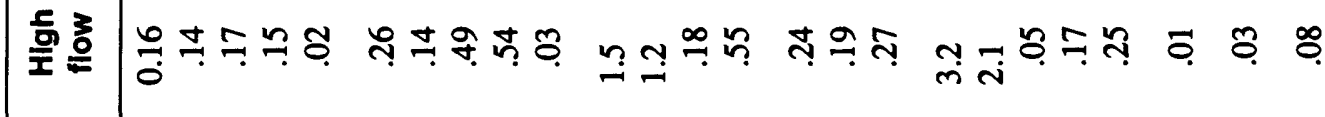

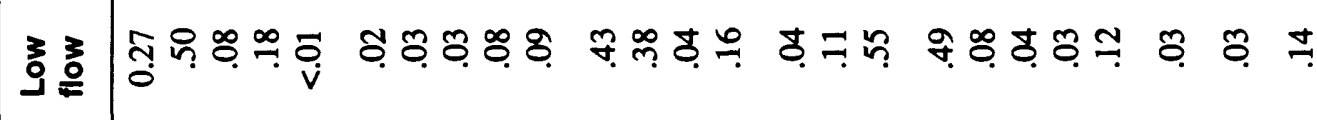

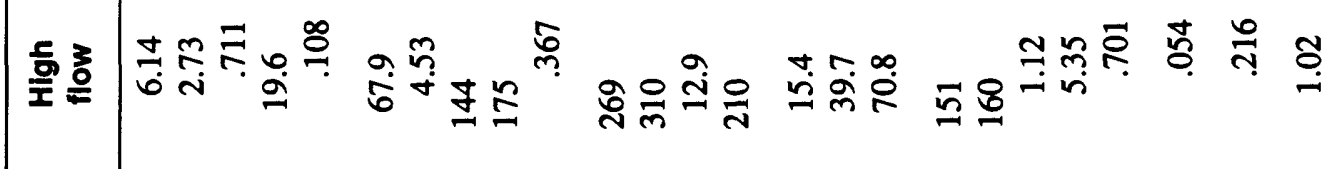

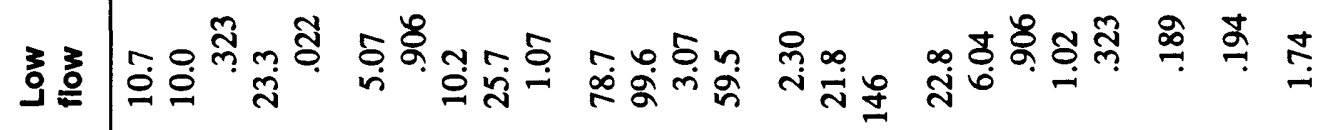

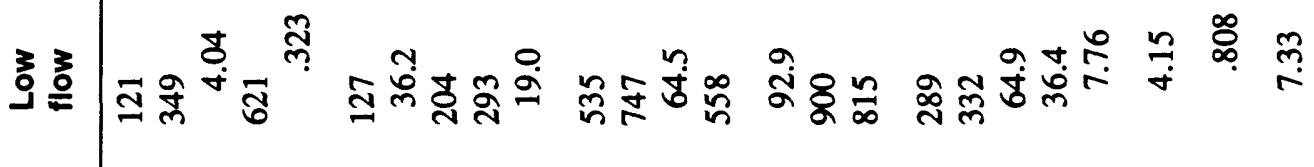

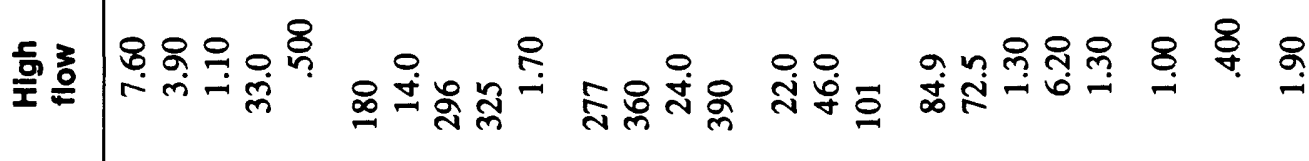

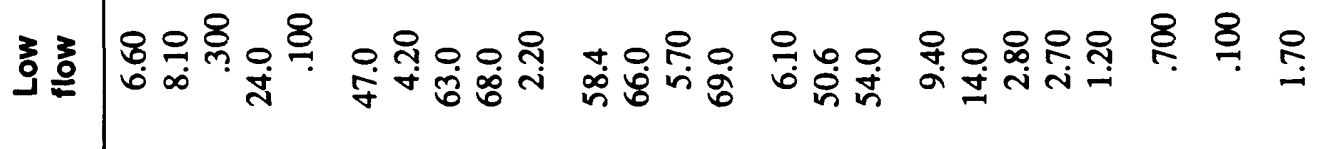

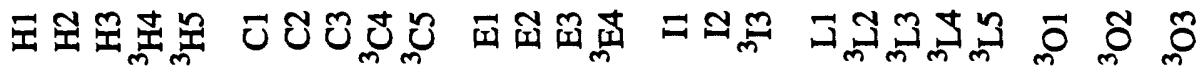

$\frac{8}{5}$

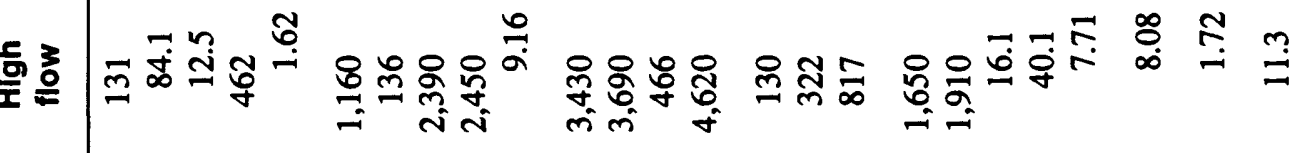




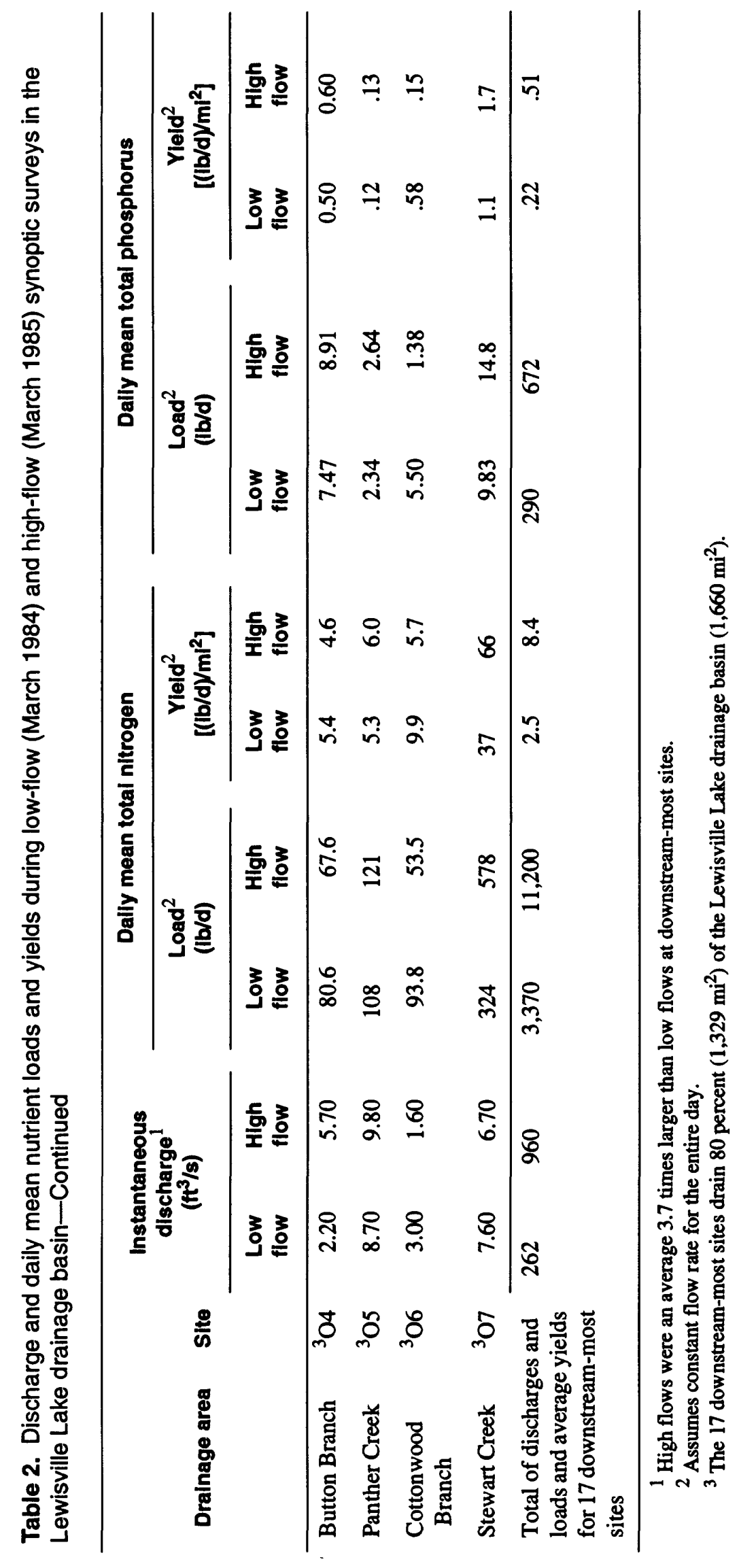


Table 3. Mean water-quality data for stormflow and periodic sampling at streamflow-gaging stations in the Lewisville Lake drainage basin, 1986-87 water years

$\left[\mathrm{ft}^{3} / \mathrm{s}\right.$, cubic feet per second; $\mu \mathrm{S} / \mathrm{cm}$, microsiemens per centimeter at 25 degrees Celsius; $\mathrm{mg} / \mathrm{L}$, milligrams per liter; $\mathrm{N}$, nitrogen; $\mathrm{P}$, phosphorus; $\mathrm{CaCO}_{3}$, calcium carbonate; $\mathrm{Ca}$, calcium]

\begin{tabular}{lccc} 
& \multicolumn{3}{c}{ Stormfiow and periodic sampling } \\
\cline { 2 - 4 } $\begin{array}{c}\text { Discharge or water-quailty } \\
\text { property or constituent }\end{array}$ & $\begin{array}{c}\text { Ciear Creek } \\
\text { near Sanger } \\
(08051500)\end{array}$ & $\begin{array}{c}\text { Little Eim } \\
\text { Creek near } \\
\text { Aubrey }\end{array}$ & $\begin{array}{c}\text { Hickory } \\
\text { Creek at } \\
\text { Denton }\end{array}$ \\
& & (08052700) & $(08052780)$
\end{tabular}

\begin{tabular}{c} 
Periodic \\
sampling \\
\hline Eim Fork \\
Trinity River \\
near Pliot \\
Point \\
(08051130)
\end{tabular}

\begin{tabular}{|c|c|c|c|c|}
\hline Instantaneous discharge $\left(\mathrm{ft}^{3} / \mathrm{s}\right)$ & 1,239 & 619 & 2,123 & 546 \\
\hline Specific conductance $(\mu \mathrm{S} / \mathrm{cm})$ & 496 & 411 & 376 & 451 \\
\hline pH (standard units) & 7.9 & 7.8 & - & 7.8 \\
\hline Nitrogen, nitrite plus nitrate, total ( $\mathrm{mg} / \mathrm{L}$ as $\mathrm{N}$ ) & .78 & 2.0 & 1.1 & .95 \\
\hline Nitrogen, ammonia plus organic, total (mg/L as $\mathrm{N}$ ) & 1.6 & 1.8 & 2.3 & 1.3 \\
\hline Phosphorus, total (mg/L as P) & .29 & .37 & .19 & .20 \\
\hline Hardness, total $\left(\mathrm{mg} / \mathrm{L}\right.$ as $\left.\mathrm{CaCO}_{3}\right)$ & 210 & 140 & 160 & 160 \\
\hline Alkalinity $\left(\mathrm{mg} / \mathrm{L}\right.$ as $\left.\mathrm{CaCO}_{3}\right)$ & 169 & 120 & 139 & 142 \\
\hline Calcium, dissolved (mg/L as $\mathrm{Ca}$ ) & 69 & 51 & 59 & 55 \\
\hline Magnesium, dissolved (mg/L) & 8.3 & 4.4 & 4.1 & 5.3 \\
\hline Sodium, dissolved (mg/L) & 34 & 32 & 20 & 32 \\
\hline Potassium, dissolved (mg/L) & 3 & 5 & 3 & 4 \\
\hline Sulfate, dissolved (mg/L) & 36 & 81 & 30 & 37 \\
\hline Chloride, dissolved (mg/L) & 54 & 12 & 14 & 34 \\
\hline Fluoride, dissolved (mg/L) & .2 & .4 & .2 & .2 \\
\hline Silica, dissolved (mg/L) & 10 & 7 & 11 & 8.7 \\
\hline
\end{tabular}

relation of major ions in the water from each stream. Linear patterns in the arrangement of data in trilinear diagrams indicate mixing of dissimilar waters (Hem, 1985). The linear arrangement of the data for Clear Creek near Sanger (fig. 4) indicates the mixing of two dissimilar waters-one dominated by calcium carbonate and the other by sodium and chloride ions. This is attributed to Clear Creek draining from the West Cross Timbers and Grand Prairie physiographic regions. Dryer soils of the West Cross Timbers region could contain more sodium chloride than the prairie soils. As waters from the two regions mix, the major-ion ratios vary relative to the proportion of water from each of the regions.

A linear pattern, to a lesser degree than that of the Clear Creek near Sanger data, also can be seen in the data for Little Elm Creek near Aubrey (fig. 4), indi- cating a mixture of calcium carbonate- and sulfatedominated water. Sulfate concentrations in Little Elm Creek generally are largest in low flows.

The data for Hickory Creek at Denton and Elm Fork Trinity River near Pilot Point indicate a calcium carbonate-dominated water (fig. 4). One sewagetreatment plant discharges above the sampling point on Hickory Creek (pl. 1).

\section{Daily Mean Nutrient Loading}

Daily mean nutrient loads for total nitrite plus nitrate nitrogen, total ammonia plus organic nitrogen, and total phosphorus were computed for each of four streamflow-gaging stations (on Clear Creek, Little Elm Creek, Hickory Creek, and Elm Fork Trinity River) (pl. 1), and for ungaged streams (collectively), in the 
Lewisville Lake drainage basin for water years 198687 (table 4). Daily mean loads for each constituent at each station were computed by summing estimates of daily Ioads to obtain annual loads and then dividing by 365. Daily mean discharge data are available for each station but not daily mean nutrient concentrations; therefore daily Ioads could not be computed directly by multiplying discharge times concentration. Estimates of daily loads were obtained from nutrient-Ioad transport equations developed for each constituent at each station by regressing log-transformed daily nutrient Ioads computed from water-sample data on logtransformed daily mean discharge. As applied, the transport equations for each constituent at each station (curves and equations shown in fig. 5) are of the form

$$
\mathrm{L}=\mathrm{B}_{2} \mathrm{Q}^{\mathrm{B}_{1}} \text {, }
$$

where $\mathrm{L}=$ nutrient load, in pounds per day,

$Q=$ discharge, in cubic feet per second, and

$B_{1}, B_{2}=$ regression coefficients.

Daily mean nutrient loads for each constituent at each station for each of the 2 water years thus were computed from the equation

$$
L=\frac{\sum_{i=1}^{365}\left(B_{2} Q_{i}^{B_{1}}\right)}{365} .
$$

Estimates of daily mean concentration for each constituent at each station (table 4) were computed by dividing computed daily mean loads by corresponding daily mean discharges.

Ungaged streams in the lake basin drain about $434 \mathrm{mi}^{2}$. On the basis of similarities in streamflow quality to waters at three gaging stations noted in analyses of synoptic samples, the ungaged area was divided into three subareas. A $243-\mathrm{mi}^{2}$ subarea was assumed similar in runoff and streamflow-quality characteristics to the Clear Creek drainage area; $33 \mathrm{mi}^{2}$ was assumed similar to the Little Elm Creek drainage area; and 158 $\mathrm{mi}^{2}$ was assumed similar to the Hickory Creek drainage area. Daily mean nutrient loads in streams draining each of the three ungaged subareas were computed as the product of the ungaged subarea and the daily mean discharge per unit area (unit runoff) of the similar gaged area and the daily mean nutrient concentration at the gaging station of the similar gaged area. The daily mean nutrient load for the entire 434-mi ${ }^{2}$ ungaged area then was computed as the sum of the daily mean loads of the three subareas. The daily mean concentration for each constituent from the ungaged area was computed by dividing the daily mean load by the daily mean discharge from the ungaged area, the discharge having been obtained by summing the products of the ungaged subareas and the respective daily mean unit-runoff values.

Nutrient-load transport equations used to compute daily nutrient loads are derived from instantaneous discharge observations; therefore, computations could result in some systematic error (bias) when discharge is not constant throughout the day. The size of this error depends on the range of variation in discharge during the day and the extent of slope (nonlinearity) of the transport curves. The magnitude of this error was assessed for several days of rapidly changing stage on Clear Creek by comparing Ioads computed by subdividing days into sections of similar discharge to loads computed from daily mean discharge. Total phosphorus Ioads computed from daily mean discharge could be 5 to 15 percent less than those computed by subdividing the day into sections of similar discharge. The total phosphorus Ioading to Lewisville Lake from Clear Creek might be underestimated because most of the total phosphorus load is associated with high flows, and high flows are associated with changing flow conditions.

The small nutrient Ioads contributed directly from precipitation on the $36-\mathrm{mi}^{2}$ lake surface were computed from precipitation records for Lewisville Lake from the U.S. Army Corps of Engineers and volume-weighted mean nutrient concentrations in precipitation collected at the National Atmospheric Deposition Program site at the Lyndon Baines Johnson National Grasslands in Alvord, Tex. (north-central Wise County), for 1986-87 (National Atmospheric Deposition Program, 1987a,b and 1988a,b).

For the water years 1986 and 1987, daily mean discharge to the reservoir (table 4) was $1,010 \mathrm{ft}^{3} / \mathrm{s}$ and $870 \mathrm{ft}^{3} / \mathrm{s}$, respectively. The total nitrite plus nitrate nitrogen that entered the reservoir on the average each day during 1986 was $5,640 \mathrm{lb} / \mathrm{d}$ and during 1987 was $4,480 \mathrm{lb} / \mathrm{d}$. During the same period, about one and onehalf as much nitrogen in the form of total ammonia plus organic nitrogen entered the reservoir $(8,530 \mathrm{lb} / \mathrm{d}$ in 1986 and 7,020 lb/d in 1987); and about one-fourth as much total phosphorus entered the reservoir during the period $(1,310 \mathrm{lb} / \mathrm{d}$ in 1986 and $1,080 \mathrm{lb} / \mathrm{d}$ in 1987). 

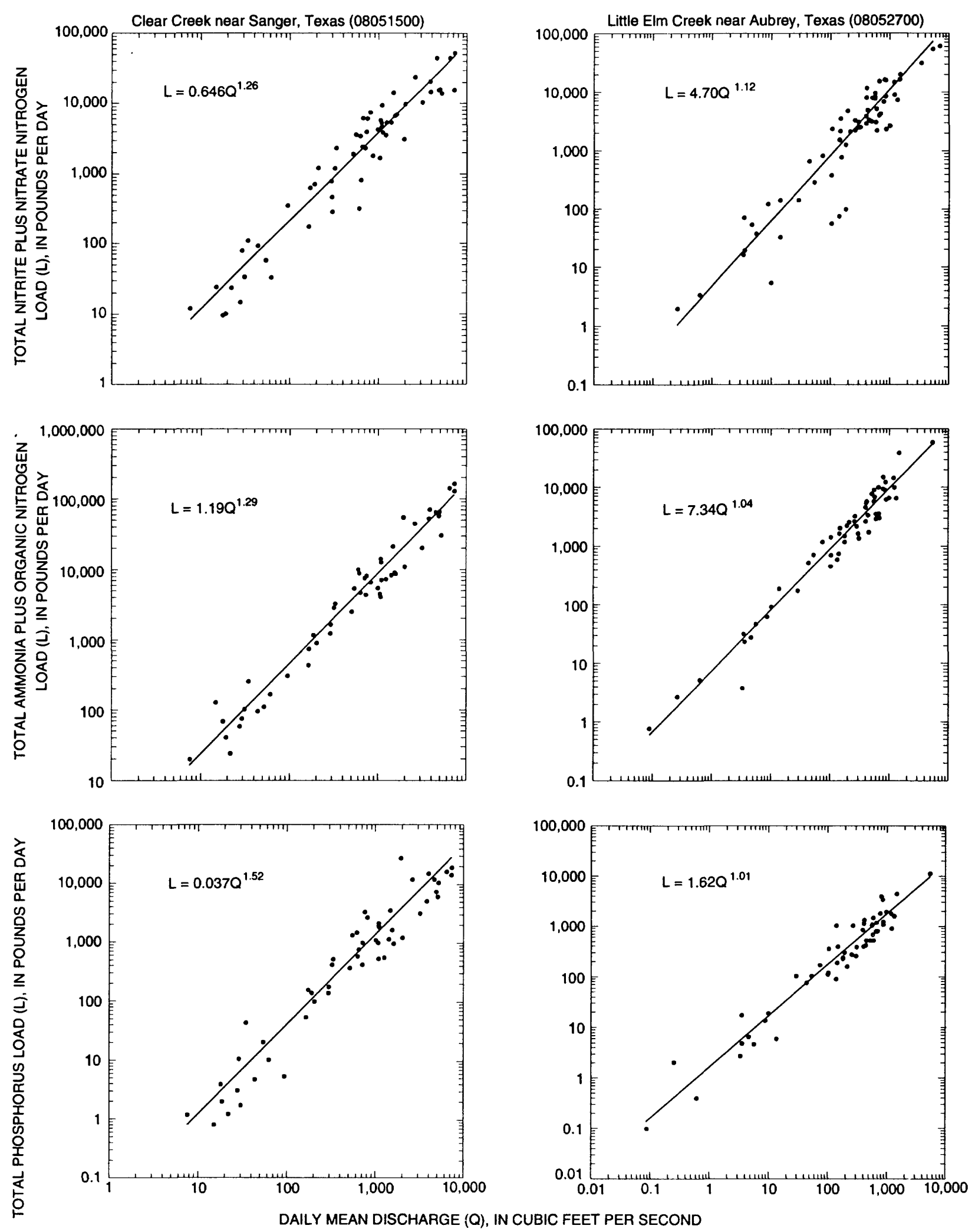

Figure 5. Nutrient-load transport curves for streamflow-gaging stations used for stormflow and periodic sampling in the Lewisville Lake drainage basin, north-central Texas, 1986-87 water years. 

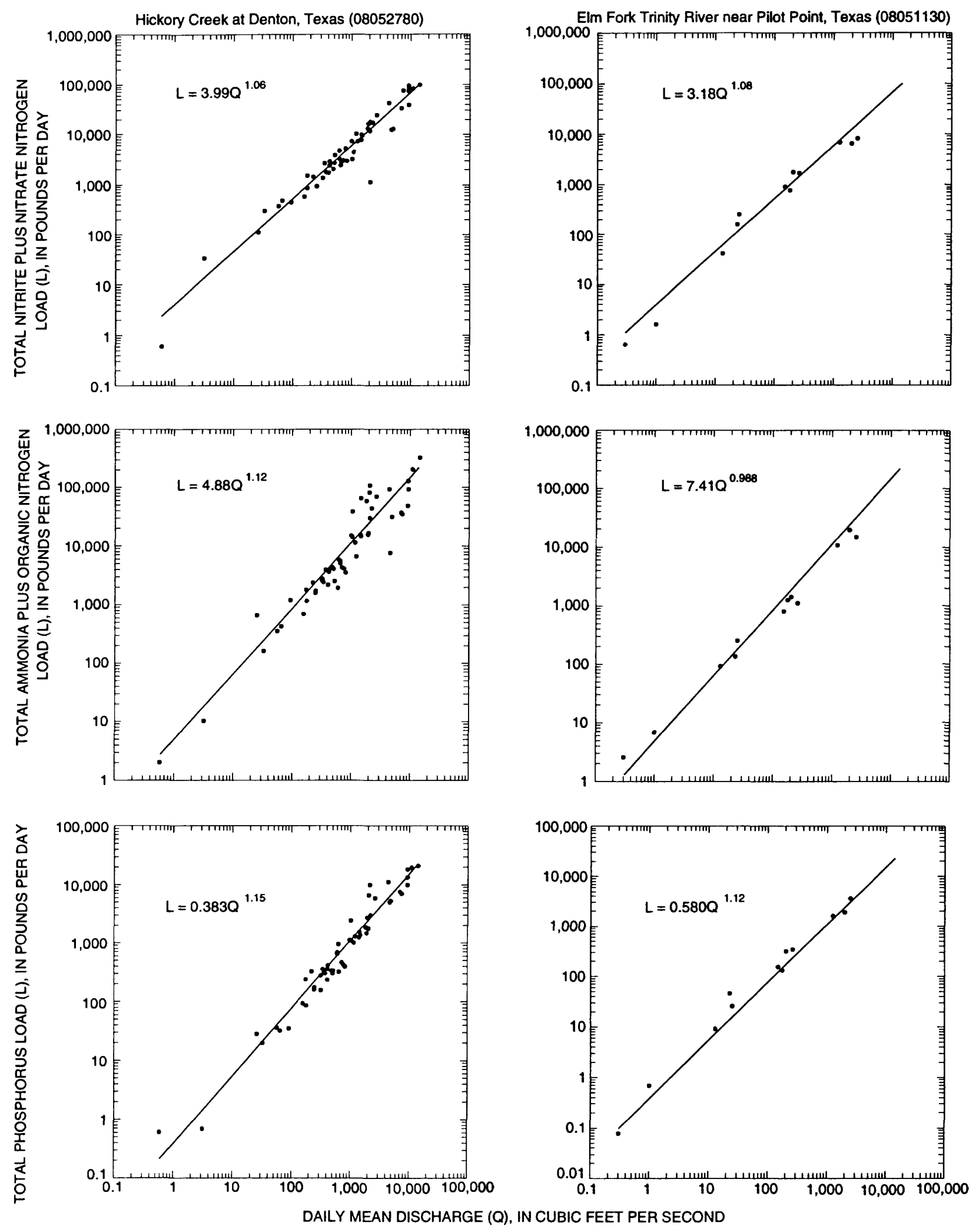


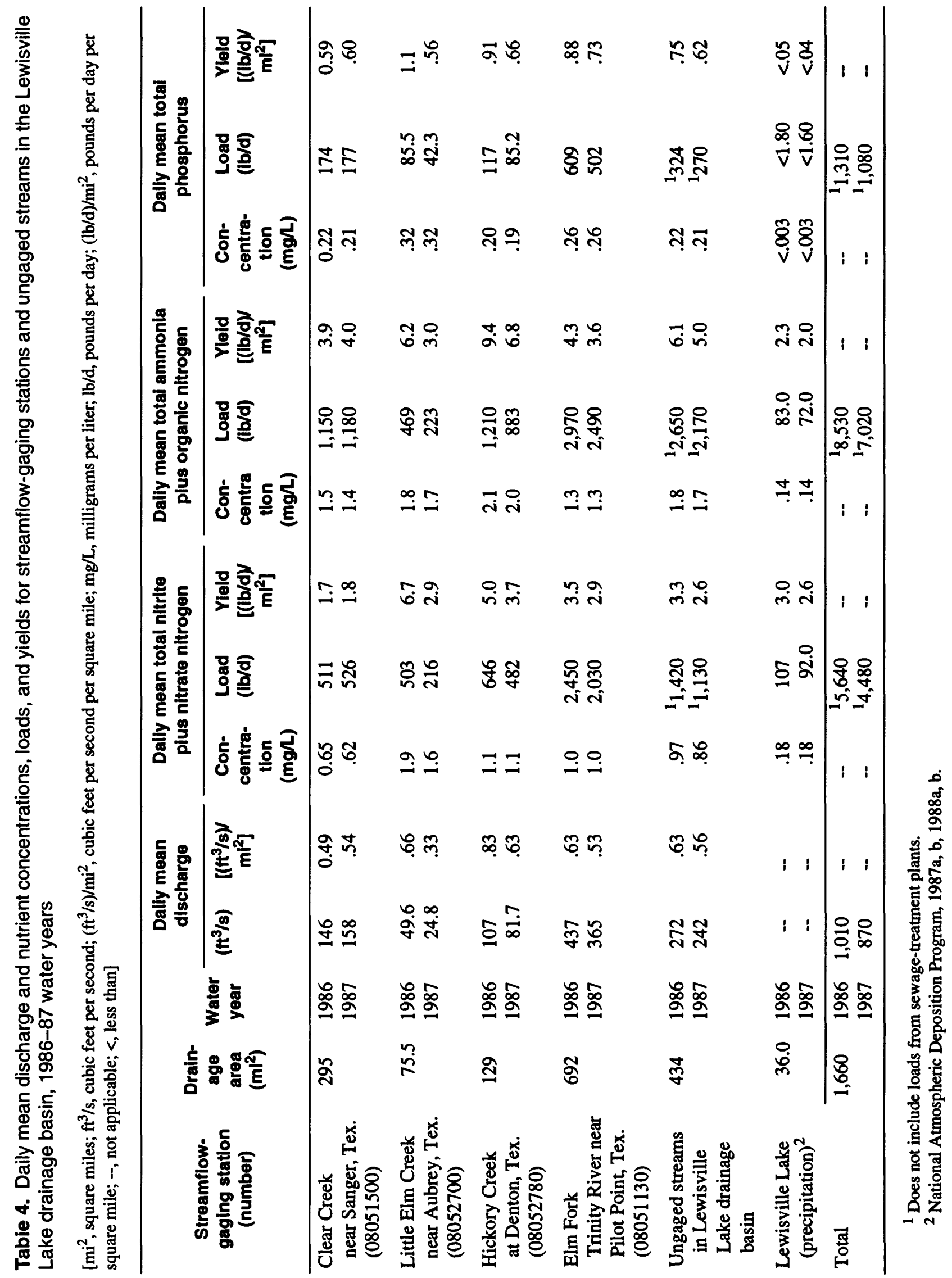




\section{Point- and Nonpoint-Source Nutrient Loading}

Loads in table 4 represent mostly nonpointsource nutrient loads. Loads from ungaged sewagetreatment plants near the lake are excluded. Although sewage-effluent discharge to Hickory Creek was negligible during the sampling period and thus was negligible in water samples from the Hickory Creek station, nutrient concentrations in samples from stations on the other three creeks probably were influenced by point sources (effluent from sewage-treatment plants).

Nutrients downstream from a point source generally are most concentrated at low flows and most diluted at high flows. Assuming nutrient discharges from point sources generally are independent of flow conditions, nutrient loads downstream from point sources generally would be more affected by the pointsource discharge at low-flow conditions than at highflow conditions. Assuming nutrient concentrations derived from nonpoint sources generally are constant, nutrient load from nonpoint sources would be low during low flow and high during high flow. On the basis of these assumptions, point sources would affect the load more during low-flow conditions and less during highflow conditions. These characteristics of low-flow and high-flow loads have been used to distinguish between point-source and nonpoint-source loads (Pillard and Dickson, 1988). To estimate the fraction of total nutrient load contributed by point sources in the gaged drainage areas, the cumulative percent of nutrient load contributed by a specific daily mean discharge during the 1986 water year was computed for each of the four streams (fig. 6). For example, about 38 percent of the total phosphorus load from Clear Creek is associated with daily mean discharges of as much as $1,000 \mathrm{ft}^{3} / \mathrm{s}$, and about 73 percent is associated with daily mean discharges of as much as $2,000 \mathrm{ft}^{3} / \mathrm{s}$. Daily mean discharges ranging from 0 to $1,000 \mathrm{ft}^{3} / \mathrm{s}$ in Clear Creek accounted for only about 38 percent of the total phosphorus load from Clear Creek to Lewisville Lake but about 65 percent of the total discharge from Clear Creek to the reservoir. Daily mean discharges ranging from 1,000 to $2,000 \mathrm{ft}^{3} / \mathrm{s}$ account for about 35 percent of the total phosphorus load but only about 22 percent of the discharge to the reservoir. Base flows (considered low-flow conditions) for the drainage areas studied, although variable during the year (fig. 2), typically were about $90 \mathrm{ft}^{3} / \mathrm{s}$ for Clear Creek near Sanger, about $10 \mathrm{ft}^{3} / \mathrm{s}$ for Little Elm Creek near Aubrey, and about $100 \mathrm{ft}^{3} / \mathrm{s}$ for Elm Fork Trinity River near Pilot Point (the three sampled streams in which point-source loading was not negligible), and about $20 \mathrm{ft}^{3} / \mathrm{s}$ for Hickory Creek at Denton. About 15 percent of total discharge and about 3 percent of the total phosphorus load in Clear Creek are associated with base-flow conditions (fig. 6). In Little Elm Creek, about 7 percent of total discharge as well as about 7 percent of the total phosphorus load are associated with base-flow conditions. In Hickory Creek, about 8 percent of the total discharge and about 3 percent of the total phosphorus load are associated with base-flow conditions. In Elm Fork Trinity River, about 5 percent of total discharge and total phosphorus load are associated with base flow. Nitrite plus nitrate load and ammonia plus organic nitrogen load associated with base-flow conditions similarly are small fractions of the total load of those constituents for the 1986 water year. On the basis of the preceding analysis and the assumptions that most of the nutrient load under conditions of base flow or less is from point sources and most of the nutrient load under conditions greater than base flow is from nonpoint sources, a small fraction (probably less than 10 percent) of the total nutrient load is from point sources.

The effects of the sewage effluent discharged into the Elm Fork Trinity River from the sewagetreatment plant near Gainesville cannot be differentiated from the effects of nonpoint-source loading. Although loads to the Elm Fork Trinity River are increased somewhat by point-source inputs, the daily mean concentration of total phosphorus for the 1986 water year in Elm Fork Trinity River $(0.26 \mathrm{mg} / \mathrm{L})$ is only slightly larger than that in Clear Creek $(0.22$ $\mathrm{mg} / \mathrm{L}$ ) (table 4). Sewage-effluent discharges to Little Elm Creek appear to increase overall concentrations of total nitrite plus nitrate nitrogen and total phosphorus in the stream; however, the load contributed by Little Elm Creek and other small streams receiving sewage effluent is small enough that exclusion of their pointsource loads from computations does not substantially change loading rates for the entire Lewisville Lake drainage basin.

Most of the point-source load to Lewisville Lake could originate at a few sewage-treatment plants in the ungaged drainage area discharging into or close to the reservoir. On the basis of data obtained from individual sewage-treatment plants, these plants discharged an average of about $19.3 \mathrm{ft}^{3} / \mathrm{s}$ during the 1986-87 water years. Total nitrogen and total phosphorus concentrations in sewage effluent have been estimated to range between 3 and $24 \mathrm{mg} / \mathrm{L}$ and between 2 and $8 \mathrm{mg} / \mathrm{L}$, 

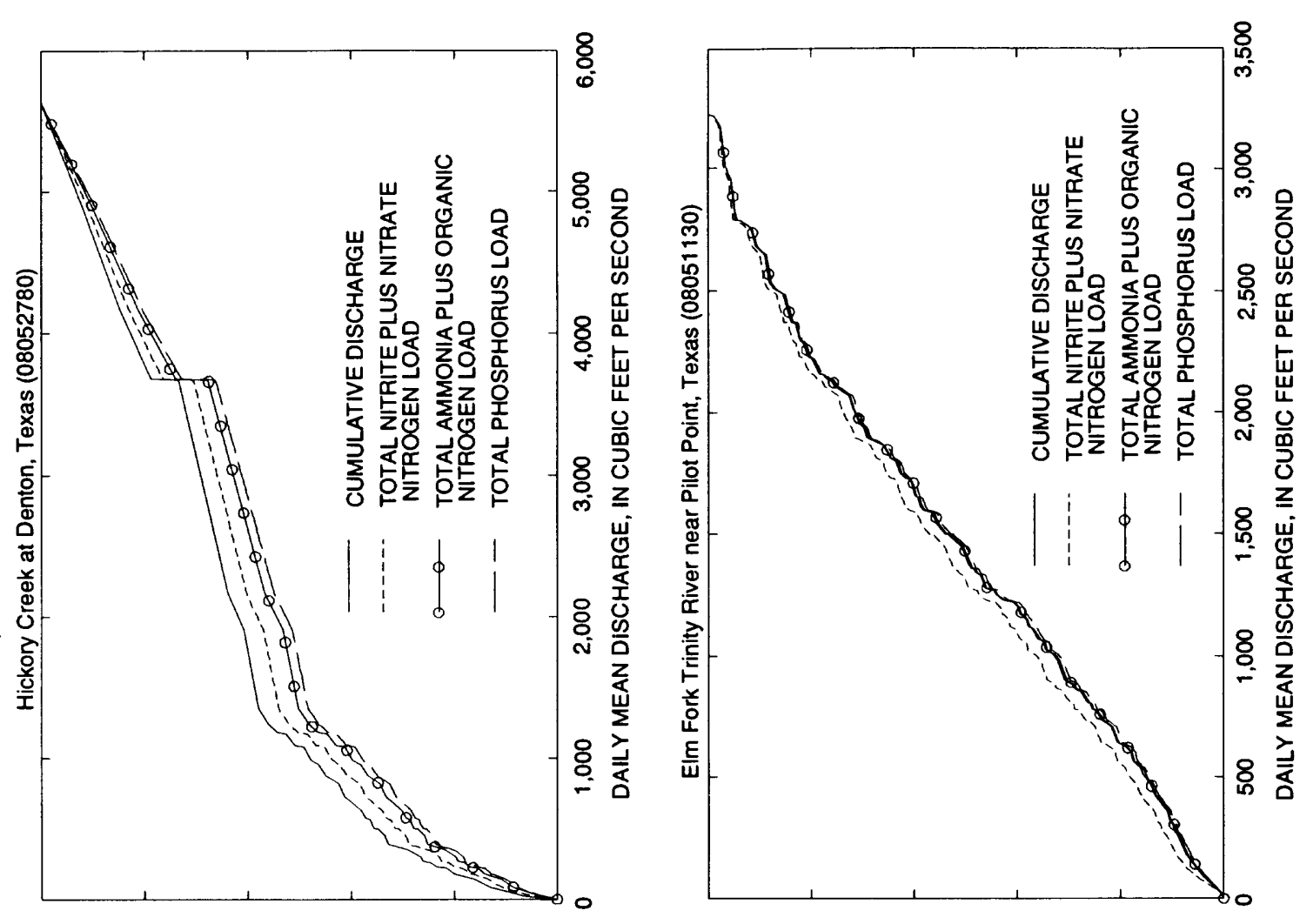

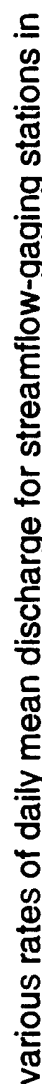
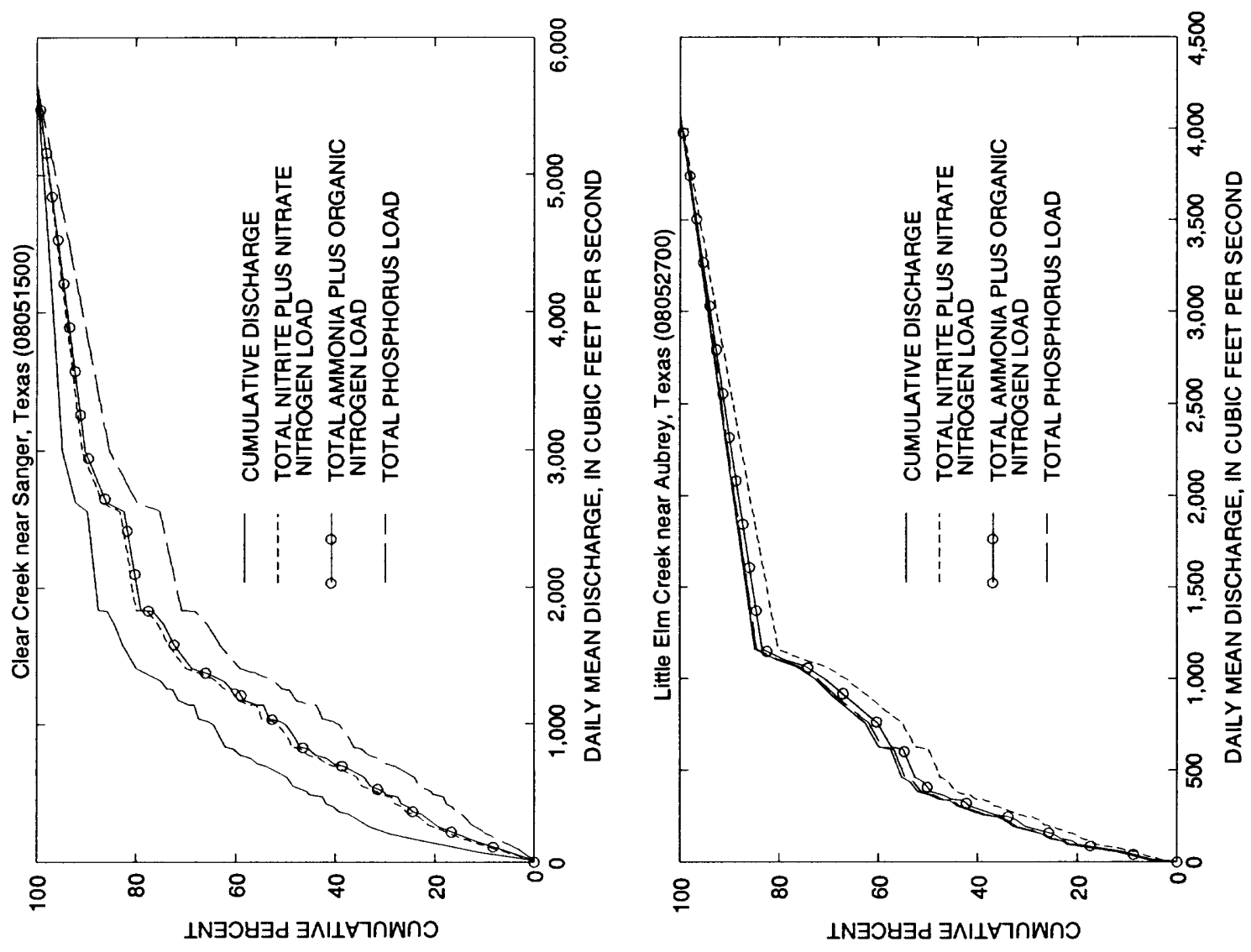

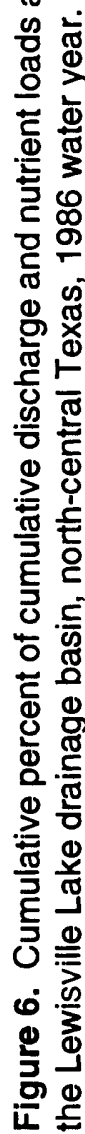


respectively (U.S. Environmental Protection Agency, 1977). On the basis of these ranges in concentration, the average point-source total nitrogen and total phosphorus loads during the 1986-87 water years from sewage-treatment plants in ungaged areas near the reservoir would range from about 310 to $2,500 \mathrm{lb} / \mathrm{d}$ and from about 210 to $830 \mathrm{lb} / \mathrm{d}$, respectively. Because loads from the sewage-treatment plants were not gaged during this study, they were not included with the loads presented in table 4.

\section{Seasonal Nutrient Loading}

Nutrient loading rates vary seasonally with discharge. Daily mean nutrient loads by month for the 1986-87 water years were computed for each of the four streamflow-gaging stations and estimated for the ungaged streams in the Lewisville Lake drainage basin (fig. 7). The maximum monthly daily mean nutrient loads were in June 1986. During that month, the daily mean total nitrite plus nitrate nitrogen load was about $17,000 \mathrm{lb} / \mathrm{d}$-more than 3 times the average annual load for the 1986-87 water years $(5,060 \mathrm{lb} / \mathrm{d}$ ) (table 5). The daily mean total ammonia plus organic nitrogen load in June 1986 was about $26,000 \mathrm{lb} / \mathrm{d}$, and daily mean total phosphorus load was about 4,200 lb/d. Minimum monthly mean loads were zero or near zero for all three nutrients in August of both water years.

Nutrient loading rates to Lewisville Lake are largest each year in three distinct seasons associated with high flow. The largest rates are usually in late spring (May-June), followed by late winter (FebruaryMarch), and late summer-early fall (SeptemberOctober). The distribution of monthly loads is expected to be similar to the distribution of monthly discharge.

\section{Annual Nutrient Loading}

Average annual total nitrogen loading to Lewisville Lake from the sources accounted for in this report for the water years $1986-87$ was about 12,800 lb/d (table 5); average annual total phosphorus was 1,200 lb/d. Nutrient loading for 1974-89 flow conditions can be estimated by multiplying the average annual nutrient loads for $1986-87$ by the ratio of average discharge to Lewisville Lake for 1974-89 to average discharge to the lake for 1986-87. The 1974-89 average annual total nitrogen load thus computed, $11,800 \mathrm{lb} / \mathrm{d}$, agrees well with the load of $11,400 \mathrm{lb} / \mathrm{d}$ estimated by DelRegno and Atkinson (1988) using satellite imaging/land-use classification (table 5). Similar results were reported by Rast and Lee (1983) using land-use relative yields. The 1974-89 average annual total phosphorus load $(1,100 \mathrm{lb} / \mathrm{d})$ also agrees well with the $1,140 \mathrm{lb} / \mathrm{d}$ estimated by DelRegno and Atkinson. Total nitrogen and total phosphorus loads from this study are more than twice those estimated by the U.S. Environmental Protection Agency (1977) (table 5).

\section{SUMMARY}

Lewisville Lake in north-central Texas, a major source of water for Dallas, could have contributed taste and odor problems to the city's water supply in recent years because of nutrient enrichment and eutrophication. This report presents seasonal variations in loading and total annual loading of total nitrogen and phosphorus to Lewisville Lake from point and nonpoint sources. The study, done in cooperation with the City of Dallas, included two periods of data collection and analysis: (1) synoptic sampling during 1984 (low flow) and 1985 (high flow) at 29 sites in the Lewisville Lake drainage basin; and (2) stormflow and periodic sampling at streamflow-gaging stations on four streams in the Lewisville Lake drainage basin during the 1986-87 water years.

Concentrations of nutrients in the streams of the Lewisville Lake drainage basin have some association with the two types of physiographic regions in the basin-prairie regions and cross timbers regions. Total nitrogen and phosphorus concentrations generally are larger in streams draining the prairie regions than in streams draining the cross timbers regions, a characteristic that might be accounted for in part by the fact that prairie regions tend to have more nutrient-rich, lesspermeable soils than cross timbers regions. Within physiographic regions, total nitrogen concentrations could not be correlated with point-source inputs (sewage-treatment plant effluent). However, total phosphorus concentrations were somewhat larger in streams that received sewage effluent than in those that did not.

Most of the variability in nutrient loads is associated with variability in discharge. During the low-flow synoptic survey, the largest contributor of total nitrogen and total phosphorus (at the downstream-most site) was Isle du Bois Creek ( $815 \mathrm{lb} / \mathrm{d}$ of total nitrogen, or 24 percent of a total of $3,370 \mathrm{lb} / \mathrm{d}$; and $146 \mathrm{lb} / \mathrm{d}$ of total phosphorus, or 50 percent of a total of $290 \mathrm{lb} / \mathrm{d}$ ). During the high-flow survey, the largest contributor of total nitrogen and total phosphorus (at the downstream-most 

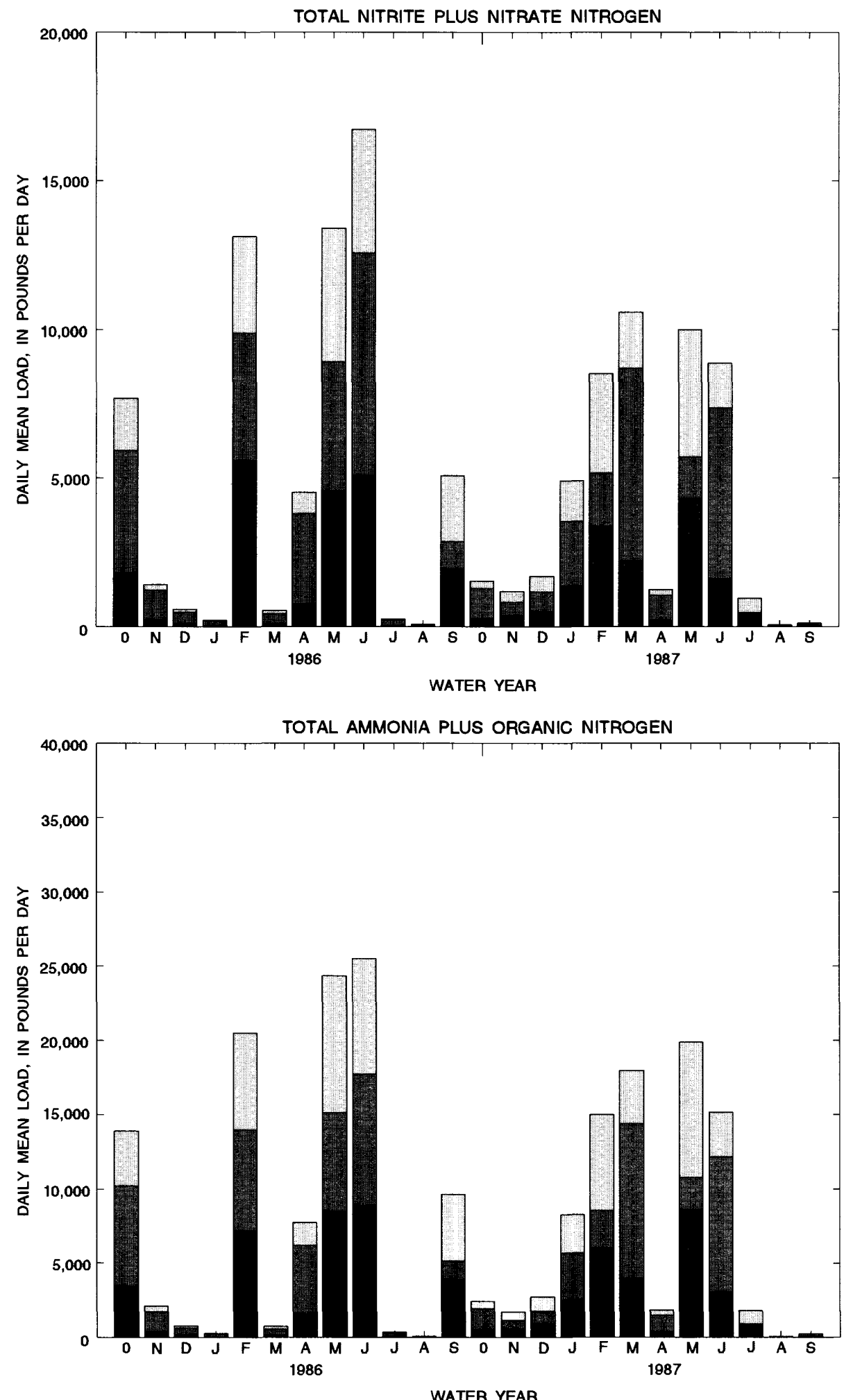

Figure $7 a$.

Figure 7. Monthly daily mean nutrient loads computed for streamflow-gaging stations and estimated for ungaged streams in the Lewisville Lake drainage basin, north-central Texas, 1986-87 water years. 


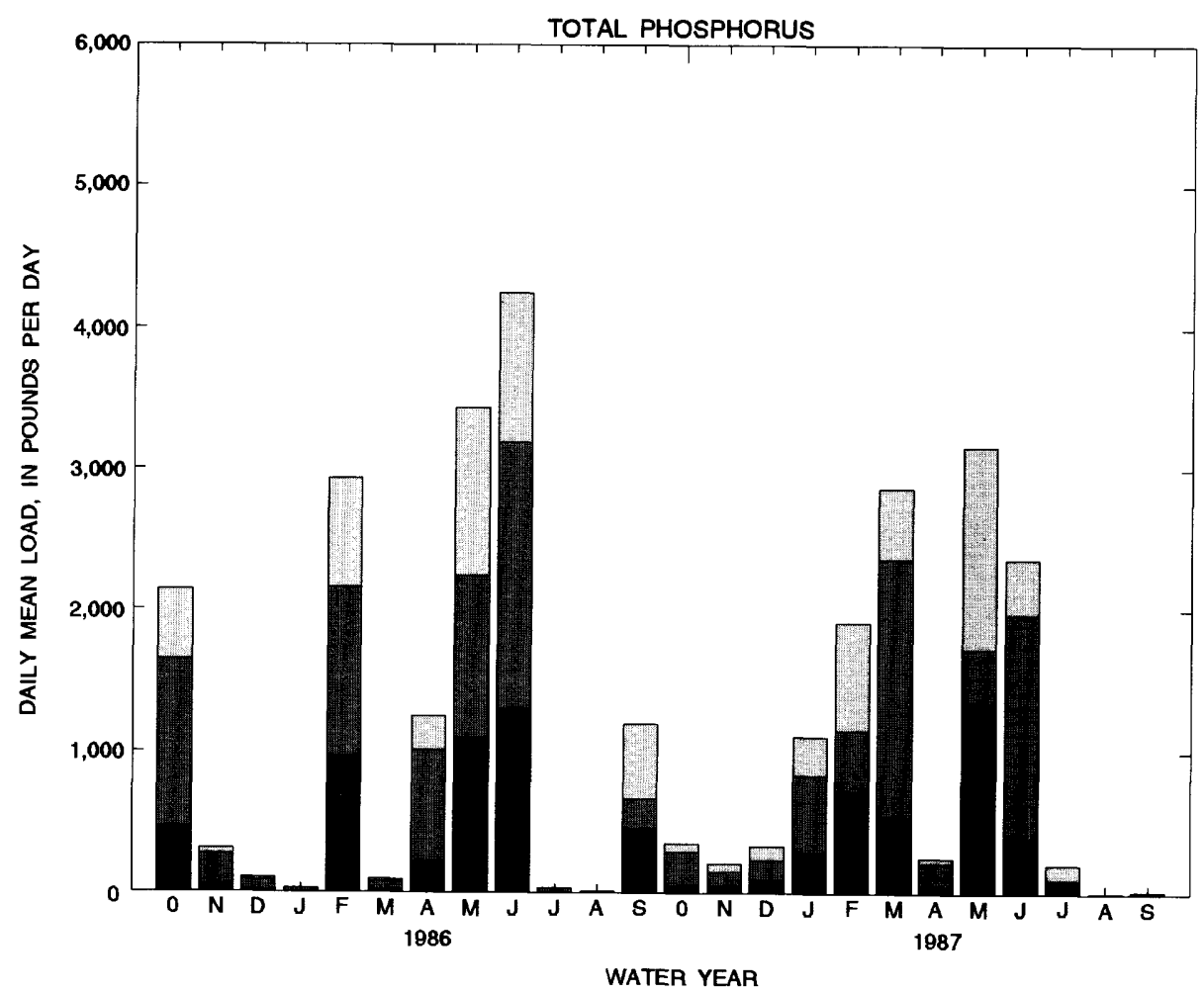

EXPLANATION

UNGAGED STREAMS

ELM FORK TRINITY RIVER NEAR PILOT

POINT, TEXAS (08051130)

HICKORY CREEK AT DENTON, TEXAS (08052780)

LITTLE ELM CREEK NEAR AUBREY, TEXAS (08052700)

CLEAR CREEK NEAR SANGER, TEXAS (08051500)

Figure $7 b$. 
Table 5. Estimates of average annual nutrient loads to Lewisville Lake

$\left[\mathrm{ft}^{3} / \mathrm{s}\right.$, cubic feet per second; $1 \mathrm{~b} / \mathrm{d}$, pounds per day; --, not applicable]

\begin{tabular}{|c|c|c|c|c|c|}
\hline \multirow[b]{2}{*}{ Source of estimate } & \multirow[b]{2}{*}{$\begin{array}{l}\text { Average } \\
\text { annual } \\
\text { inflow } \\
\left(\mathrm{ft}^{3} / \mathrm{s}\right)\end{array}$} & \multicolumn{4}{|c|}{ Average annual load } \\
\hline & & $\begin{array}{l}\text { Total nitrite } \\
\text { plus nitrate } \\
\text { nitrogen } \\
\text { (lb/d) }\end{array}$ & $\begin{array}{l}\text { Total ammonia } \\
\text { plus organic } \\
\text { nitrogen } \\
\text { (lb/d) }\end{array}$ & $\begin{array}{c}\text { Total } \\
\text { nitrogen } \\
\text { (lb/d) }\end{array}$ & $\begin{array}{c}\text { Total } \\
\text { phosphorus } \\
\text { (ib/d) }\end{array}$ \\
\hline $1986-87$ water years (this study) ${ }^{1}$ & 940 & 5,060 & 7,780 & 12,800 & 1,200 \\
\hline $1974-89$ (this study) ${ }^{1}$ & ${ }^{2} 865$ & 4,660 & 7,160 & 11,800 & 1,100 \\
\hline DelRegno and Atkinson (1988) & -- & - & - & 11,400 & 1,140 \\
\hline $\begin{array}{l}\text { U.S. Environmental Protection Agency } \\
\text { (1977) }\end{array}$ & -- & - & -- & 4,660 & 492 \\
\hline $\begin{array}{l}\text { Point sources (sewage-treatment plants } \\
\text { in ungaged area) }{ }^{3}, 1986-87 \text { water years }\end{array}$ & 19.3 & - & - & $4310-2,500$ & $5_{210-830}$ \\
\hline
\end{tabular}

${ }^{1}$ Excluding sewage-treatment plants in ungaged areas.

2 Mean annual outflow, 1974-89, at U.S. Geological Survey streamflow-gaging station Elm Fork Trinity River near Lewisville $(08053000) 688 \mathrm{ft}^{3} / \mathrm{s}$ (U.S. Geological Survey, 1975-90) + $177 \mathrm{ft}^{3} / \mathrm{s}$ computed from gross evaporation, 1940-65 (Texas Water Development Board, 1966) and assuming static lake volume.

${ }^{3}$ Individual sewage-treatment plants (unpub. data, 1991).

${ }^{4}$ Concentrations from 3 to 24 milligrams per liter estimated by the U.S. Environmental Protection Agency (1977).

${ }^{5}$ Concentrations from 2 to 8 milligrams per liter estimated by the U.S. Environmental Protection Agency (1977).

site) was Elm Fork Trinity River $(4,620 \mathrm{lb} / \mathrm{d}$ of total nitrogen, or 41 percent of a total of $11,200 \mathrm{lb} / \mathrm{d}$; and 210 $\mathrm{lb} / \mathrm{d}$ of total phosphorus, or 31 percent of a total of 672 $\mathrm{lb} / \mathrm{d})$.

Average nutrient yields (loads per unit area) for the 80 percent of the Lewisville Lake basin included in the synoptic surveys were 2.5 and $8.4(\mathrm{lb} / \mathrm{d}) / \mathrm{mi}^{2}$ of total nitrogen and 0.22 and $0.51(\mathrm{lb} / \mathrm{d}) / \mathrm{mi}^{2}$ of total phosphorus in the low-flow and the high-flow surveys, respectively. Some of the largest yields in both surveys were from the three streams receiving the largest amounts of sewage effluent-Elm Fork Trinity River, Little Elm Creek, and Stewart Creek.

On the basis of the results of stormflow and periodic sampling, the total nitrite plus nitrate nitrogen that entered the reservoir on the average each day during 1986 was 5,640 lb/d and during 1987 was $4,480 \mathrm{lb} / \mathrm{d}$. During the same period, about one and one-half as much nitrogen in the form of total ammonia plus organic nitrogen entered the reservoir $(8,530 \mathrm{lb} / \mathrm{d}$ in 1986 and 7,020 lb/d in 1987); and about one-fourth as much total phosphorus entered the reservoir during the period $(1,310 \mathrm{lb} / \mathrm{d}$ in 1986 and $1,080 \mathrm{lb} / \mathrm{d}$ in 1987).

An analysis of time distributions of streamflow and nutrient loading during the 1986 water year was done to estimate the fraction of total nutrient load con- tributed by point sources in the four gaged drainage areas. Point sources accounted for small fractions (probably less than 10 percent) of the total nutrient load from Clear Creek, Little Elm Creek, Hickory Creek, and Elm Fork Trinity River.

Most of the point-source load to Lewisville Lake could originate at a few sewage-treatment plants discharging to ungaged streams close to the reservoir. The average point-source total nitrogen and total phosphorus loads during the 1986-87 water years is estimated to range from about 310 to $2,500 \mathrm{lb} / \mathrm{d}$ and from about 210 to $830 \mathrm{lb} / \mathrm{d}$, respectively.

Nutrient loading rates vary seasonally with discharge. Rates are largest each year in the three seasons of highest flows. The largest rates are usually in late spring (May-June), followed by late winter (February-March), followed by late summer-early fall (September-October).

The estimated long-term (1974-89 water years) average annual total nitrogen load (excluding loads from sewage-treatment plants in ungaged areas) is $11,800 \mathrm{lb} / \mathrm{d}$. The estimated long-term (1974-89 water years) average annual total phosphorus load (excluding loads from sewage-treatment plants in ungaged areas) is $1,100 \mathrm{lb} / \mathrm{d}$. 


\section{REFERENCES}

Austin, M.E., 1965, Land resource regions and major land resource areas of the United States (exclusive of Alaska and Hawaii): U.S. Soil Conservation Service, Agriculture Handbook 296, 82 p.

DelRegno, K.J., and Atkinson, S.F., 1988, Nonpoint pollution and watershed management-a remote sensing and geographic information system (GIS) approach: Lake and Reservoir Management, North American Lake Management Society, 4(2):17-25.

Ford, Alan, and Pauls, Ed, 1980, Soil survey of Denton County, Texas: U.S. Soil Conservation Service, 160 p.

Gain, W.S., 1989, Physical and chemical data from two water-quality surveys of streams in the Lewisville Lake watershed, north-central Texas, 1984 and 1985: U.S. Geological Survey Open-File Report 89-285, 2 sheets.

Guy, H.P., and Norman, V.W., 1970, Field methods for measurement of fluvial sediment: U.S. Geological Survey Techniques of Water-Resources Investigations, book 3, chap. C2, 59 p.

Hem, J.D., 1985, Study and interpretation of the chemical characteristics of natural water (3d ed.): U.S. Geological Survey Water-Supply Paper 2254, 264 p.

Inman, R.L., and Conover, W.J., 1983, A modern approach to statistics: New York, John Wiley, 497 p.

Lee, G.F., Jones, R.A., and Rast, W.R., 1980, Availability of phosphorus to phytoplankton and its implications for phosphorus management strategies, in Loehr, R.C., Martin, C.S., and Rast, W.R., eds., Phosphorus management strategies for lakes: Ann Arbor, Ann Arbor Science Publishers Inc., p. 259-308.

Lee, G.F., Meckel, E., Abdul-Rahman, M., Gary, M., Moore, M., McDonald, M., Cale, W.G., and Rast, W.R., 1977, Lake Ray Hubbard eutrophication report: Richardson, Tex., Center for Environmental Studies, University of Texas at Dallas, 388 p., submitted to Dallas Water Utilities.

National Atmospheric Deposition Program, 1987a, NADP/NTN data report-precipitation chemistry, 1 January-30 June, 1986: Fort Collins, Colo., Natural Resource Ecology Laboratory, Colorado State University, v. IX, no. 1,210 p.

1987b, NADP/NTN data report-precipitation chemistry, 1 July-31 December, 1986: Fort Collins, Colo., Natural Resource Ecology Laboratory, Colorado State University, v. IX, no. 2, 216 p.

1988a, NADP/NTN data report-precipitation chemistry, 1 January-30 June, 1987: Fort Collins, Colo., Natural Resource Ecology Laboratory, Colorado State University, v. X, no. 1, 217 p.

1988b, NADP/NTN data report-precipitation chemistry, 1 July-31 December, 1987: Fort Collins,
Colo., Natural Resource Ecology Laboratory, Colorado State University, v. X, no. 2, 216 p.

Organization for Economic Cooperation and Development, 1982, Eutrophication of water-monitoring assessment and control: Paris, Organization for Economic Cooperation and Development, $154 \mathrm{p}$.

Pillard, D.P., and Dickson, K.L., 1988, Pre-impoundment estimations of nutrient loading to Ray Roberts Lake and prediction of post-inundation trophic status: Denton, Tex., Institute of Applied Sciences and Department of Biological Sciences, North Texas State University, $208 \mathrm{p}$.

Rantz, S.E., and others, 1982, Measurement and computation of streamflow: U.S. Geological Survey WaterSupply Paper 2175, $631 \mathrm{p}$.

Rast, W.R., and Lee, G.F., 1978, Summary analysis of the North American (U.S. portion) OECD Eutrophication Project—nutrient loading-lake response relationships and trophic state indices: U.S. Environmental Protection Agency, Ecological Research Series, EPA-600/3$78-008,455 \mathrm{p}$.

1983, Nutrient loading estimates for lakes: Journal of Environmental Engineering, v. 109, no. 2, p. 502-517.

Redfield, A.C., Ketchum, B.H., and Richards, F.A., 1963, The influence of organisms on the composition of sea water, in Hill, M.N., ed., The sea: New York, WileyInterscience, v. 2, p. 26-77.

Ryding, S.O., and Rast, W.R., 1989, The control of eutrophication of lakes and reservoirs-programme on man and the biosphere, v. 1: United Kingdom, United Nations Educational, Scientific and Cultural Organization (UNESCO), Parthenon Press, p. 49-58.

Skougstad, M.W., Fishman, M.J., Friedman, L.C., Erdmann, D.E., and Duncan, S.S., 1979, Methods for determination of inorganic substances in water and fluvial sediments: U.S. Geological Survey Techniques of WaterResources Investigations, book 5, chap., A1, $626 \mathrm{p}$.

Texas Water Development Board, 1966, Monthly reservoir evaporation rates for Texas, 1940 through 1965: Texas Water Development Board Report 64, p. 52-53.

Texas Water Quality Board, 1976, Wasteload evaluation for effluent limiting segment no. 0823 of the Trinity River: Texas Water Quality Board.

U.S. Environmental Protection Agency, 1977, Report on Lake Lewisville (Garza-Little Elm): National Eutrophication Survey Working Paper 649, February 1977.

U.S. Geological Survey, 1981-91, Water resources data for Texas, water years 1980-90-v. 1: U.S. Geological Survey Water-Data Reports TX-80-1 to TX-90-1.

University of Texas, Bureau of Economic Geology, 1967, Geologic atlas of Texas, Sherman sheet: Austin, University of Texas, Bureau of Economic Geology map. 